\title{
The Humanities in Transition from Postmodernism into the Digital Age
}

The Humanities in Transition explores how the basic components of the digital age will have an impact on the most trusted theories of humanists. Over the past two generations, humanists have come to take basic postmodern theories for granted whether on language, knowledge or time. Yet Michel Foucault, Jacques Derrida and similar philosophers developed their ideas when the impact of this digital world could barely be imagined. The digital world, built on algorithms and massive amounts of data, operates on radically different principles.

This volume analyzes these differences, demonstrating where an aging postmodernism cannot keep pace with today's technologies. The book first introduces the major influence postmodernism had on global thought before turning to algorithms, digital space, digital time, data visuals and the concept to digital forgeries. By taking a closer look at these themes, it establishes a platform to create more robust humanist theories for the third millennium. This book will appeal to graduate students and established scholars in the Digital Humanities who are looking for diverse and energetic theoretical approaches that can truly come to terms with the digital world.

Nigel A. Raab is professor of Russian history at Loyola Marymount University, Los Angeles, California. 


\section{Routledge Studies in Cultural History}

Cultural Organizations, Networks and Mediators in Contemporary Ibero-America

Edited by Diana Roig-Sanz and Jaume Subirana

Soldiers and Their Horses

Sense, Sentimentality and the Soldier-Horse Relationship in The Great War

Jane Flynn

The Magic Lantern at Work

Witnessing, Persuading, Experiencing and Connecting

Edited by Martyn Jolly and Elisa deCourcy

Women Photographers of the Pacific World, 1857-1930

Anne Maxwell

How Books, Reading and Subscription Libraries Defined Colonial Clubland in the British Empire

Sterling Joseph Coleman, Jr.

Russia's French Connection

A History of the Lasting French Imprint on Russian Culture Adam Coker

Transatlantic Encounters in History of Education

Translations and Trajectories from a German-American Perspective Edited by Fanny Isensee, Andreas Oberdorf, and Daniel Töpper

The Humanities in Transition from Postmodernism into the Digital Age Nigel A. Raab

For more information about this series, please visit: www.routledge. com/Routledge-Studies-in-Cultural-History/book-series/SE0367 


\section{The Humanities in Transition from Postmodernism into the Digital Age}

Nigel A. Raab 
First published 2020

by Routledge

52 Vanderbilt Avenue, New York, NY 10017

and by Routledge

2 Park Square, Milton Park, Abingdon, Oxon, OX14 4RN

Routledge is an imprint of the Taylor \& Francis Group, an informa business

(C) 2020 Taylor \& Francis

The right of Nigel A. Raab to be identified as author of this work has been asserted in accordance with sections 77 and 78 of the Copyright, Designs and Patents Act 1988.

All rights reserved. No part of this book may be reprinted or reproduced or utilised in any form or by any electronic, mechanical, or other means, now known or hereafter invented, including photocopying and recording, or in any information storage or retrieval system, without permission in writing from the publishers.

Trademark notice: Product or corporate names may be trademarks or registered trademarks, and are used only for identification and explanation without intent to infringe.

Library of Congress Cataloging-in-Publication Data

Names: Raab, Nigel A., 1968- author.

Title: The humanities in transition from postmodernism into the digital age / Nigel A. Raab.

Description: New York : Routledge, 2020. I Series: Routledge studies in cultural history; vol 89 I Includes bibliographical references and index.

Identifiers: LCCN 2020015959 (print) I LCCN 2020015960 (ebook) I ISBN 9780367896799 (hardback) | ISBN 9781003020493 (ebook) | ISBN 9781000091465 (adobe pdf) I ISBN 9781000091472 (mobi) | ISBN 9781000091489 (epub)

Subjects: LCSH: Digital humanities. I Postmodernism. I CulturePhilosophy.

Classification: LCC AZ105 .R28 2020 (print) I LCC AZ105 (ebook) I DDC 001.30285-dc23

LC record available at https://lccn.loc.gov/2020015959

LC ebook record available at https://lccn.loc.gov/2020015960

ISBN: 978-0-367-89679-9 (hbk)

ISBN: 978-1-003-02049-3 (ebk)

Typeset in Sabon

by Apex CoVantage, LLC 
To the city of Los Angeles, my city of inspiration 
$\because$ Taylor \& Francis

Taylor \& Francis Group

http://taylorandfrancis.com 


\section{Contents}

Acknowledgments

viii

1 Introduction 1

2 The Achievement of Postmodernism 23

3 The End of the Linguistic Turn 43

4 The End of Theory in the Humanities $\quad 70$

5 The Influence of Algorithms on Humanistic Thought 89

6 Digital Space 110

7 Digital Time 130

8 Data Visuals 147

9 Digital Forgeries 161

10 Conclusion 176

Bibliography 190

Index 200 


\section{Acknowledgments}

The thanks for every book should really be longer than the book itself, but I will keep it short. A big thank you to Max Novick at the press for his guidance. Once again, I have to thank Alice Raab, who in another era would have been a master editor at a major publishing house. She turns clotted prose into something readable and saves me from all my bad intellectual habits. I also must thank the anonymous readers who did much of the same by forcing me to clean up shaky ideas and drop anchors where I started to drift. My dad, Tony, has always encouraged me to seek new thoughts and pursue my dreams. Carolyn Peter, my wife, is the sounding board for so many crazy schemes. She is the warm soul whose sensitivity fills every room of our house, and without her I would probably be little more than moss on a log.

Venice Beach, 2020 


\section{Introduction}

Well over a generation ago, a movement arrived on the academic scene and spurred a series of energetic debates that engaged the brightest minds on both sides. In the aftermath of World War II, a younger generation was ready for a fundamental reassessment of the Western project. If the Nazis were a reflection of a Western value system born in the Enlightenment of the eighteenth century, then the system was corrupt at its core. In the words of philosophers and literati, the core was formed by a rational worldview that could be as stifling and repressive as Enlightenment thinkers had believed it to be liberating. Rationality was the heart of the death star and had to be destroyed.

Combatant metaphors serve well because any attempt to undermine rationality was quickly challenged by traditional scholars who were convinced that the Western tradition with its emphasis on objectivity and rationality had improved the lot of human beings on planet earth. These scholars mocked the idea that knowledge was relative, that the outcome of science was the result of mob rule in the laboratory, and that human rights were a cultural construct. This stubbornness drew battle lines that were fought on many fronts, and these serious battles continued for decades.

As this division spread into curricula in colleges around the world, the academic environment became polarized between postmodernists and their predecessors. Postmodernists rejected attempts to save the Western tradition and urged their students to denounce male hegemony, discourses of power, and modern imperialism on the basis of some form of relativism. Much like the Slavophiles and Westernizers in Russia in the 1840s, the two groups could no longer walk on the same side of the street. Allan Bloom equated the demotion of the works of great white men with the closing of the American mind, as he titled his book. ${ }^{1}$ Turning in the opposite direction, postmodernists saw their mission as the opening of the American mind and continued to fight vigorously against scholars such as Bloom.

Back then, postmodernism was in its early adulthood and acted with an energy appropriate to its age. If we can pin its adolescence to the seminal works by Jacques Derrida and Michel Foucault in the 1960s, by the 


\section{Introduction}

1980s it was a mature and widespread force that sought its own place in the sun. This was a well-deserved place, and with time, postmodernists no longer had to worry about being silenced. In the 1960s, to suggest that science was socially constructed was radical and ran up against massive criticism from outside the humanities. Nowadays, to say otherwise is to invite massive criticism from within the humanities. Postmodern ideas slowly entered the mainstream-checking a box marked gender rather than one marked sex comes to mind-and their vision was accepted, if reluctantly and with certain reservations, by the rest of the academy. Even if this was by no means a clear victory, shared space had been achieved.

But what happens to a movement once it achieves its main goals? In the 1920s, many suffragists were at a loss because now that women had the right to vote, they were not sure what to do. In the Soviet Union, dissident artists struggled with perestroika precisely because art designed to disrupt censorship laws lacked oxygen when the censorship laws were reduced or eliminated. Similarly, postmodernism lost much of its flair not because it was objectively wrong, but because it became commonplace. Instead of harnessing youthful energies, it became a tool for established scholars who were satisfied with a few pithy references to postmodern theories. If mention of the 'gaze' brought excitement and bewilderment in the 1970s, it has now become a cliché lacking vital signs. One need only look at the basic vocabulary in numerous current books. Readers will see frequent references to discourse, language, agency, social construction, cultural construction, and more. In fact, with the aging of postmodernism, some ideas have taken on the quality of a truth, the idea they were designed to oppose. References to social construction are presented as absolutes; to proclaim an event or a tradition as socially constructed is to proclaim a self-evident truth. In accepting the notion in such an unquestioning fashion, intellectuals are unwittingly reversing the direction of the postmodern impulse. The adolescent has aged and, like us all, struggles to cope in a new environment as trends change and innovations shift our thinking.

The most energetic and dynamic challenges come from the digital world. Scholars have been adapting to technological change for generations, but few could predict the sweeping impact of digital technologies. Whether in public life, in the scientific laboratory, or amongst humanists, the digital influence is never far away. In the most straightforward instances, it is a source of marvel because of the ease with which it makes information accessible; curious individuals can create web platforms and spread their ideas more broadly. In San Francisco, the Internet Archive has preserved massive amounts of web data, searchable and available for research projects. On the surface, all these innovations sound like practical tools that simply facilitate larger, more ambitious undertakings.

It is too convenient, however, to think of these digital technologies as mere instruments that assist the completion of ongoing projects. The 
digital milieu represents a caesura with older methods for any number of reasons. In fact, the digital world collides with many standard postmodern themes. Unfortunately, the collision of postmodern theory with the digital world has been presented as unproblematic, especially in volumes such as Debates in the Digital Humanities where one regularly comes across references to discourses, epistemologies, and narratives as if they function no differently in a digital environment. ${ }^{2}$ In a similar spirit, David J. Bodenhamer writes, "the use of appropriately cast spatial technologies ... promises to develop a unique postmodern scholarship." ${ }^{3}$ Alternatively, scholars present digital research as a practical and straightforward empirical affair. In Digitization in the Real World, the editors note this is "a book written by practitioners for practitioners" on the process of digitization; it is not interested in the interpretive impact. ${ }^{4}$ As a result, little attention has been paid to analytical contradictions in the following domains: the discord between Big Data's link to positivist methods of the nineteenth century and postmodernism's basic mistrust of quantification; how digital translation tools have challenged the concept of linguistic incommensurability; the tension between social time of the postmodernists and the universal time which exerts an enormous influence in the digital environment; and the rapid increase in data visuals at the expense of traditional text in humanist scholarship.

All too often the answer to the digital challenge is to look backwards, not forwards. Instead of thinking about how postmodern ideas have to be adjusted to digital realities, the same terms and vocabulary are introduced as a humanist counterthrust to the digital impulse. In her article Humanistic Theory and Digital Scholarship, Johanna Drucker recognizes the potential danger of the Digital Humanities and stresses that "if we are to assert the cultural authority of the humanities in a world whose fundamental medium is digital," theories from the humanities must have a critical purchase on digital platforms. ${ }^{5}$ Although this could not be more true, she advocates the promotion of humanistic theories-poststructuralism, postcolonialism, and deconstruction-that were developed more than half a century ago. How can theories developed in the 1960s in a completely different historical environment stand as a bulwark against the excesses of the digital age?

Time and again, there is a reluctance to move on from standard themes and standard vocabularies, as if no matter what happens in the external world, the same postmodern premises can offer an adequate solution. In a commemorative edition of Derrida's Of Grammatology, Gayatri Chakravorty Spivak downplays the technological revolution. The "cybernetic and infometrics revolution" is dismissed because its revolutionaries "are using not a new discourse to fix the new inventions, but versions of the millennial ethnocentric and Europacentric ideology of the thinking of Europe." In brackets, she adds, "The World Wide Web works on psychologistic and positivistic reductions of the ideas of text, recovery, 


\section{Introduction}

memory, access, and especially, interaction." ${ }^{6}$ The comments are ironic because they appear in the 40th Anniversary edition and give the impression that nothing has changed since the first edition appeared in France. It is not enough to dismiss cybernetics and infometrics with tools that were developed in the middle of the twentieth century. Many of the celebrated aspects of postmodernism are ill-suited to a contemporary world so distant from Paris of the 1960s, where postmodernism first gained momentum.

The digital world is not incommensurable with postmodernism, but one cannot assume that postmodern ideas can operate timelessly in any environment; it as an inherent corollary to postmodernism that its natural force will erode. The accomplishments of postmodernism do not have to be denied, but the achievement must be met with critical eyes to see both where its energies are still vibrant and where the spirit has waned. The energies are best revealed by highlighting the brazen ventures whose lasting impact is not always self-evident. Within the ivory tower and out on the street, postmodern gestures are ubiquitous if often unrecognized, as so much of its accomplishments go unnoticed. There is no contradiction celebrating success as a lifetime achievement award, while recognizing that the recipient is no longer at the summit of her career. It becomes necessary to evaluate those aspects of the canon that demand more urgent change. In the spirit of the idea that every end is a new beginning, the postmodern predilection for language and theory deserves a more critical eye because these positions are nearing their end. The end of the linguistic turn and the end of theory may ring overly dramatic, yet these two crutches of the postmodern generation need a deeper evaluation because they simply cannot exist in the same way in the digital environment.

Digital developments have presented humanists with convenient tools which are shifting basic methodologies and, as a consequence even if yet unspoken, are nibbling away at the underlying premises of postmodernism. For example, the algorithm is a common buzzword, almost an invective at this point, but little effort has been made to examine how basic decision-making processes within an algorithm impact humanist theories. Since humanists have actually started to employ algorithms, the basic principles have to be contextualized relative to older conceptual models. Similarly, the relevance of Big Data requires elucidation in a multifaceted manner. From its basic principles to its modification of concepts of space and time to its visualization in any number of forms, Big Data must be better positioned vis-à-vis postmodernism because to simply accept Big Data is to undermine postmodernism altogether. Conversely, to reject it in favor of a naïve allegiance to postmodernism is to live in an age other than our own. A closer look creates a more congenial atmosphere for the two even if one partner is definitely the elder statesperson. In addition to these digital concerns, the discussion is rounded out with words on digital forgeries. Because postmodernism was so concerned with blurring the boundaries between fact and fiction, forgery is 
an exemplary test case that has yet to receive the philosophical attention it merits: what is a digital forgery, and does it have the same authorial and epistemological connotations of art forgeries that have been the subject of such fascination over the years? The subject of forgery, complex in the simplest of times, confirms the old saw that there is always more work to be done. All these issues need elaboration, but the path to clarity must begin by understanding the postmodern achievement, tracing its waning powers, and then examining what happens in the digital age.

Stripped of much of its tedious jargon, postmodernism was at heart a celebration of human diversity and the complex qualities of life: the qualities that fill us with emotion, make us see many colors where previously we saw only one, and distinguish between the sounds in our environments. In this sense it took its lead from Nietzsche, who was truly of the earth, explored all our inner instincts, and situated humans in a world of plants, animals, and diverse geographical terrain. It took a relativistic interpretation from Nietzsche to argue that truths were social constructs, the mind a convenient fiction, and the world a home to fluctuating values.

Practically and indirectly, postmodernism opened the way to accepting cultural achievements. Bypassing Mozart and Beethoven as the standards of excellence, Westerners reluctantly came to realize that other cultures had rather complex musical schemes that produced enjoyable sounds. Instead of viewing African artistic production as magical native crafts, as Picasso did at the ethnographic museum at the Palais du Trocadéro in the early twentieth century, philosophers of a postmodern persuasion argued that crafts was a derogatory term that denied these cultures an artistic aesthetic. ${ }^{7}$ On the street level, this meant that postmodernism was instrumental in moving non-European artistic creation from museums of natural history to bona fide art museums. Although this took decades, eventually this process would be promoted by individuals who had no direct connection to postmodernism. To repurpose words of Isaiah Berlin intended for positivists, the postmodernists had done their work so well, they no longer needed to be mentioned. ${ }^{8}$

A similar phenomenon lies with the simple shift from sex to gendera simple shift that took an enormous amount of intellectual energy but is now something that, far from being locked into a theoretical ivory tower, has an accessible public moment every time someone fills out a form. And it is more than filling out forms. The word 'gender' as mentioned earlier incorporates options and diversity that were more limited when an applicant filled the rectangle marked 'sex' with either male or female. That box became a window through which one could see oneself in many ways-homosexual, heterosexual, transgendered, and anything in between. Identity is by no means a solved problem, but when that window is opened, a breeze of broad acceptance fills the room.

The study of science also underwent change and was a significant battleground because it represented the most protected bastion of objectivity. On the heels of Thomas Kuhn's Structure of Scientific Revolutions, 


\section{Introduction}

postmodernists pressured scholars to look for subjectivity in science. ${ }^{9}$ If James Conant had presented his readers with objective sketches of measurement devices, a generation later Steven Shapin and Simon Schaffer looked at how the seventeenth-century air-pump was situated in religious and political representations. ${ }^{10}$ Using extensive references to Foucault, they argued that science was as much about discursive acts as it was about laboratory experiments. To be sure, many of these arguments were overdrawn and too many historians flogged the discourse of science, but science is now analyzed more holistically.

The net is being cast widely, and maybe too much credit is being given to postmodernism. One can come to respect other cultures and value their achievements without dipping into relativism and rather arcane theories of language (Johanna Drucker gives the mistaken impression that poststructuralism and its kin are the only prisms through which to glimpse the aesthetic life). ${ }^{11}$ Because Mozart's operas were rejected as a universal standard, some circles forgot about Mozart altogether. When this happened, we can sympathize with Allan Bloom and his talk about the closing of the American mind; a narrow approach to theoretical innovation closed many minds.

Postmodern arguments were designed to invite controversy, but in the main, more avenues were opened than closed. Although it took decades, fields of research broadened out as philosophers promoted a world without a center, a world of pluralistic inquiry. The central focus was the dynamic possibilities of human expression. The emphasis was on the qualitative and not quantitative aspects of human life, whether as studied by the historian or by the philosopher or by the literary critic. Historians, for example, left quantitative research to quantitative disciplines. This pleased humanists because in a technological century, they no longer had to justify themselves against the hard sciences (since they gained a degree of self-confidence having debunked the objectivity of science). This was great news at the end of the second millennium.

Although the achievements deserve acquaintance, shortcomings are of more consequence when studying transitions because they show the position of postmodernism as it was about to bump up against digital realities. This is an opportunity not to argue that the original was wrong but that the original idea lost its compass as the energies waned. This is particularly true with respect to the linguistic turn and the philosophy of language. The philosophy of language predates postmodernism by a number of generations, and it is no exaggeration to suggest that the twentieth century was the century of the philosophy of language. Leonard Bernstein argued that music was language, Christian Metz maintained that film was a language, and Arthur Danto posited that an artwork was akin to a text. Ultimately, it became the cause célèbre of postmodernists and therefore warrants closer attention so the role of language in a digital environment will be understood in the largest context possible. 
The postmodern approach was to take the philosophy of language and employ it in the service of relativism. It began with the premise that all knowledge was mediated through language (a premise that is nowadays often forgotten) and built a number of outcomes from that position. In its pithiest form, the linguistic turn is expressed in Derrida's popular slogan: there is no hors texte; nothing exists outside of language. Thereafter, studies put linguistic usage on center stage. It gave the impetus to seminal works such as Hayden White's Metahistory. ${ }^{12}$

Those in favor of the linguistic turn were not arguing that language was important, for that has been clear ever since the Bible asserted God gave humans the word. Nor, in the spirit of Johann Gottfried Herder, were they taking the origins of language from God and placing it in the hands of humans. ${ }^{13}$ Rather, they were arguing that the primary factor in the formation of knowledge was language, and therefore they gave language the primary epistemological role; language became more than primus inter pares. This role had previously been dominated by theological or metaphysical ponderings. With this step taken, it was another short step to argue two principal positions. First, knowledge was a social construction dependent upon linguistic conventions of individual communities. Second, to control language was to exercise power. This last version relates to the link Foucault made with discourse and power that inspired humanists up and down the line.

Soon variants of these ideas became commonplace, though they were all based on postmodern assumptions. Hayden White contended that the structure of historians' prose could be compared with the structure of fictional prose, thus suggesting that this stylistic fiction was more central than the objective facts historians wanted to present to their readers. The blurring of the lines between historical fact and fiction was a key postmodern strategy. Other scholars argued that totalitarian states were successful because they managed to control the language or build a new civilization with a few well-placed expressions. Over the years, language gained a hegemonic position, shoving alternatives to the periphery. Linguistic usage, however, has become a much more data-driven affair, upsetting notions of discourse that thrived in a purely humanistic world. As databases become more available, humanists will be tempted to employ the methodologies of cognitive linguists who have been collecting language samples for years.

To be sure, the linguistic turn was instrumental in destabilizing objectivity. Along the way, however, it employed linguistic ideas selectively and pushed numerous alternatives to the side. In reviewing the literature of the 1980s and 1990s, one cannot avoid the impression that analytic philosophers and cognitive linguists were conveniently ignored. In worst cases, these philosophers were used indiscriminately to do no more than drive home the same point over and over again. Random invocations of Ludwig Wittgenstein, a philosopher of language in the British analytic 


\section{Introduction}

tradition, litter the landscape. Wittgenstein's language game, a prominent concept in Shapin and Schaffer's seminal work on the history of science, has suffered more than its fair share of abuse. It is deeply unfortunate that Wittgenstein employed the term game because it has become associated with the loose play, the playfulness of the postmodernist, rather than the complex rule-oriented system of the analytical philosopher. Over and over again, the expression is invoked to mean that two sides were doing different things (playing different games), though no linguistic evidence or linguistic rules are presented to substantiate the claim. How can one know the boundary between two language games if both sides are speaking English?

Rarely, if ever, are such questions addressed. In the process, linguistic rules, grammatical forms, verb tenses, or other complexities find no place in the discussion. The dominant form is to focus on select words and draw conclusions from there, though words represent a tiny fraction of the complete structure of language. In the heyday of the linguistic turn, such methods could be excused because they were part of the excitement of a young movement. Now, however, these are signs that the time has come to move on.

The concept of distant reading is symbolic of emerging challenges to a twentieth-century understanding of the linguistic turn. In a book of the same title, Franco Moretti has taken aim at the common postmodern practice of close textual analysis. ${ }^{14}$ Instead of dissecting the multiple valences of a single word, Moretti established a digital laboratory that canvasses the appearances of words in thousands upon thousands of written texts; Moretti's laboratory could offer a literary interpretation without anyone on the team actually having read the novel or all the novels in the sample. The approach differs dramatically from Derrida, who looked for multiple traces in each word. Nor does it resemble a Geertzian thick-or-thin description, as the digital approach has a method of its own. Although distant reading is both a real and metaphorical confrontation with the linguistic turn, it does not fully flesh out those increasingly unacceptable components of the linguistic turn.

In particular, the dynamic elements of the linguistic turn have dissipated over time. The original philosophical puzzles that intrigued Wittgenstein and his followers are now gathering dust, as linguistic analysis is being equated with basic linguistic usage. Scholars make assertions about the language of specific cultures or societal groups to point out that these people used language and meant something by it. Hardly the most fascinating idea. They rarely pay attention to grammatical forms or philosophically re-evaluate the relationship between language, the external world, and our own biological composition. Most such suggestions are met with resistance and the reassertion of sweeping claims about the social construction of language. 
In his early work, the Tractatus-logico-philosophicus, Wittgenstein wrote about the limits of language, a theme that sounds familiar to postmodernism. He recognized that language had limits, but these were not the limits of experience since something operated on the other side of language. ${ }^{15}$ One of his central points was that certain things, such as spirituality, existed outside the trivial contours of linguistic usage. In this vein, all sorts of experiences—-sound, touch, odor, vision-have nothing to do with language at all, nor need they be translated into some form of language. If we begin to recognize this, though many historians of the senses still adhere to discursive methodologies, this silent admission will open new doors and admit changes into the applicability of postmodern ideas.

This plea to end the linguistic turn is not asking to end the study of language. It seeks only to attenuate the dominance of language. Language should be neither the omnipresent arbiter nor the holistic umbrella under which all studies find themselves; then it falls in the hegemonic trap of philosophy before it. The inquisitive mind will want alternatives and a means to visit those parts of the world whose existence begins before language and ends outside of it. Moreover, tools such as Google Translate have changed the rules dramatically and have effectively eliminated linguistic incommensurability. To recognize this shifting terrain, one has to look at how the linguistic turn has been unsettled. By examining the original euphoria that accompanied it, one gets a better sense for its sweeping impact and the blind devotion it encouraged. It then sets a foundational position to see clearly where the digital age forces a divergent path upon us.

In its application, the linguistic turn was surrounded by a nimbus of theory. Not all authors understood the theories, but they happily and often carelessly referred to theoretical slogans such as the hors texte. This came about because a fascination with language was tied to postmodernism's association with theory. Over the centuries, disputes have regularly pitted scholars against each other, but only postmodernists were involved in a dispute called the theory wars.

As the theory wars were such an intense part of postmodern identity, talk of the end of theory must sound like heresy. While the idea was conceptually impossible for a combatant of the 1980s to grasp, 'the end of theory' has become an increasingly popular word sequence that pops up in unexpected places. In 2008, Chris Anderson published an article with the phrase in the title. ${ }^{16} \mathrm{He}$ argued that the traditional method of scientific theory-making had lost its effectiveness. Since algorithms analyzed data without a real-world understanding of that data and could still present identifiable and meaningful trends, the older methods no longer had any function. Data processors could independently identify trends and actively provide solutions to problems. Not everyone has agreed with this 


\section{0}

controversial proposition, but it nevertheless demonstrates that scientists will have to shift their perceptions of theory. ${ }^{17}$

Theory in a scientific milieu differs from theory in a humanistic milieu, but Anderson's assertion should not be ignored. Humanists successfully showed that scientists were not immune to social forces and thus humanists will not be immune to scientific forces. Research which involves databases has become so common amongst humanists, they too will be subject to the same pressures as scientists. Of course, the end of theory would come as quite a blow, especially for scholars such as Quentin Skinner who wrote about the "Return of Grand Theory." ${ }^{18}$ For theory to return in the 1980s only to then disappear a generation later represents quite a conundrum. Yet there can be no doubt that the presence of data in the humanities will change the theories we choose and the manner in which we understand what a theory is.

As Skinner's title suggests, the process being considered is one of departures, returns, and arrivals. As such, the transition must be considered in a broad historical time frame, for an expression such as the return of grand theory suggests theory had its moment, was replaced by something, and then reemerged. If we accept that chain of events, then the potential end of theory represents another moment of departure. These ups and downs require historical perspective, because if it was acceptable for Skinner to write about the return of theory, then something akin to the end of theory might equally be considered the return of something else.

For this reason, the number one suspect for a return is positivism, a movement most postmodern theories were designed to reject. Yet the surge of modern data production has many commonalities with Comtean positivism-collect data on human activities upon which to make sweeping claims (the potential resurgence of positivism has already been noted in a variety of circles). Auguste Comte emphatically rejected the abstraction of theologians and metaphysicists before him, so he represents a movement against the abstract theories so popular amongst postmodernists. Postmodernists were neither theologians nor metaphysicists, but they promoted abstract theories that did not require mass data.

Comte was not fundamentally against theory, as he did search for general laws, but he was against abstract theorizing. To fully contextualize Comte's version, the road from his positivism to today's world of Big Data needs to be traced insofar as it pertains to conceptual theories. On the one hand, Comte's positivism, in whatever mutated form, had a massive impact until the 1950s. On the other hand, almost immediately after he introduced his ideas in the 1830s and 1840s, voices were heard calling for more abstract theorizing and less of a dependency on naïve factuality. If Comte's positivism stressed a deep empirical bias, thinkers such as Wilhelm Dilthey pushed for more abstraction. Soon thereafter, the European intellectual world took theorizing to its limits as more and more abstract impulses guided intellectual and artistic creation. Theorizing was 
detaching itself from realism and advocating new constellations. Martin Heidegger was deeply troubled by shifts in theory, and the postmodernists later built on this trend in the middle of the twentieth century. The postmodern upswell came precisely at that time when philosophers were ready to declare the death of positivism. It took a hundred years, but factbased proclivities were finally replaced by abstract theorizing.

It is this historical process that needs to be examined because it puts the contemporary pressure on theory into context. Moreover, it opens a space to discuss how the arrival of data will invite more positivist trends. Even if we accept that the original positivism has worn thin, emerging strands of a positivist approach are a corollary to the current theoretical transformation: not in the urform Comte desired (few self-proclaimed academic positivists followed him anyway), but in a form that shows greater respect for well-ordered facts, facts researchers have come to depend upon in the digital age. This theoretical rupture thus becomes a singular moment to re-evaluate conceptual schemes when the return of grand data is nudging aside the return of grand theory.

Once this historical and theoretical excursus has exposed initial problems for postmodernism in the digital age, one can put the conversation on a digital footing and investigate applications in the digital world. The foremost candidate in this regard is the algorithm, because the algorithm produces a massive amount of directed data. Chris Anderson wrote, "statistical algorithms find patterns where science cannot." ${ }^{19}$ The power of the algorithm has become well known, almost legendary, and it has emerged as a dominant player. Rather than dissecting the algorithm to reveal its mathematical nuts and bolts, one must take a closer look at the algorithm in a manner the humanist can understand.

The reluctance of humanists to dig into mathematics is no surprise, and one does not necessarily need to heed a call to code. Nevertheless, more effort is required to see how the nature of algorithmic decision-making runs up against the postmodern canon. Postmodernists railed against binary decision-making, yet this underlies fundamental algorithmic commands; an algorithm cannot function without logical commands that depend on binary operations. The output of the algorithm does not have to create a binary, but all the decisions that result in that output do. How can one deny binaries while depending upon them?

Algorithms as active tools in the humanities have been around for a relatively short time, but they have already been evaluated. In what is to be expected, humanists have pointed out that Google algorithms, far from representing objective mathematics, can have socially disturbing outputs. In Algorithms of Oppression, Safiya Noble has shown troubling racist and gendered outcomes that are often unknown to the producers of the algorithms. ${ }^{20}$ These important analyses are, however, embedded in a postmodern language and focus on the empirical output of the algorithm. Noble writes of the gendered discourse these algorithms produce, 


\section{Introduction}

a sentence that might well have appeared in a postmodern work of the mid-1980s. The producer of data is new, but the analysis follows a familiar road. The thornier question about the theoretical impact of the algorithm on discourse theory is left aside for what might be considered more pressing practical matters. Noble's work directly addresses a grave contemporary concern, but it still treats the algorithm as a black box with a disconcerting output. When we probe into that black box, unexpected discoveries will shift conceptual frameworks and reveal new dilemmas. ${ }^{21}$

Alternatively, the algorithm can be situated in a variety of helpful contexts that make a logical phenomenon of structural interest to humanists. For example, every algorithm has a feedback loop that returns a past answer into a future decision. This immediately suggests a complex attitude to time within the calculation. More directly, the feedback loop can be compared to Derrida's notion of the trace, an idea that involves a lingering past presence in the future of an object; no object is pure unto itself. The two concepts may come from different worlds, but the parallels will reveal similarities. A determined postmodernist will simply want to harness the feedback loop to Derrida's idea, to subordinate it to the trace, but that would obscure changes that Derrida could not have foreseen.

Algorithms also present a unique opportunity to think about the layers of language. Programming code has often been designated as a language, so the reference immediately positions it next to comfortable theoretical friends. In resisting the temptation to gamble on weathered clichés, the analysis looks at the layered quality of programming code and the barrier that separates the internal code from its translated expression in the external world. These layers operate simultaneously yet perform different functions and express basic linguistic qualities, such as time, in different ways. An exercise attuned to the particular linguistic qualities of algorithms again attenuates the omnipresence of the linguistic turn.

Algorithms are not the only producers of data, but they increasingly play that role. It therefore makes sense to examine the producer of data before looking at the data itself. Once the algorithm has been explained in a humanistic manner, attention can turn to the data and individual instances of this massive data production. In 2010, then Google CEO Eric Schmidt told his audience in Lake Tahoe, California, that "from the dawn of civilization to 2003, five exabytes were created. The same amount was created in the last two days." 22 The claim is wishy washy but makes the point that Big Data is upon us, and, as an extension of the idea, increasingly so in the work of humanists. A historian today can avoid Big Data, but a generation from now scholars will be studying individuals whose decisions were guided by the data of algorithms. In the future, scholars will be studying past generations who themselves read digitally-born digital readers. Historians and archivists will also have to do their best to preserve the databases stored in private and public collections around 
the world. Philosophers will be no less immune because moral decisions become increasingly steered by data trends.

Big Data is a popular term but is not always well defined, being even more metaphorical than Moretti's distant reading. The term first surfaced in the 1990s and came to embody data accumulation in the digital age. ${ }^{23}$ Despite the quantitative adjective, Big Data is not a mere measurement but an attitude; one does not just cross a numeric threshold to enter into the world of Big Data. Since it is considered a qualitative term, its definition has been more difficult to pin down as scientists and humanists have tried to give it an adequate description. Its technological side has been defined with reference to the three Vs: volume, variety, and velocity. The three Vs suggest that sophisticated technological hardware and software are at play when processing Big Data. As the technologies for processing Big Data have gained in sophistication, the definition has been refined over and over again; the three Vs have become five.

Many of these definitions require a technological understanding, but Big Data does not always have to be presented in technical detail. It can be more simply referred to as data which is too big for a normal computing device to handle. This definition is loose, but it can be lightly modified to fit the parameters of its usage in the pages that follow. Big Data is large enough to force humanists to interact in a radically innovative way with their source material; their normal procedures are inadequate to the task. It implies an unfamiliar interaction with knowledge whose importance far outweighs the size of the data itself. For the humanist, the presence of Big Data alters space, time, and even the way we view things.

The first of three chapters involving Big Data explores our understanding of digital space, since it can be said that a database occupies no space at all. To be sure, data is stored on physical servers that absorb intense amounts of energy, but the stored data is unlike the physical objects that were always at the heart of most empirical studies. In an odd way, space gets transformed when it enters a database. For example, Foucault's panopticon depended on a real-world spatial positioning, one in which sightlines traveled through space. In contrast, the Digital Panopticon project, a database of nineteenth-century English prisoners, has eliminated that space altogether. Instead, it has parsed and divided all the prisoners who no longer resemble physical or dimensional objects. They can be reconstituted based on specific characteristics, but they cannot leave the database with the same spatial characteristics with which they entered. The Wayback Machine from the Internet Archive also has a strange relationship with space because it stores digitally born websites. The stored websites may represent objects outside the digital world, but the websites themselves never had a third dimension, and the Wayback Machine pays no attention to this third dimension.

These spatial oddities ultimately impact an understanding of facts and knowledge. What is the nature of a digital fact if an original object gets 


\section{4}

dismantled, stored as a fragment in a database, and then can be reconstituted in any number of ways? What space does this fact occupy if it occupies any space at all? Similarly, what happens to local knowledge in this environment? These questions expose the notion that a massive flood of information has peculiarities that require elucidation. The nature of facticity will change immensely. Since these enormous databases are essentially an intermediary of experience, one might say they contain no facts at all. Yet from the other perspective, these are some of the most reliable facts scholars have ever had. These twin poles highlight a problem and demand that the facticity of Big Data be given a little more attention; the facts can then be linked with the act of digital knowing.

One should not be fooled into believing that Big Data will become a totalitarian experience, eliminating conventional experiential sources altogether. Sources that persist in traditional dimensions, what might be called Little Data, will continue to intersect and impact Big Data. How will humanists integrate the quantities of digital facts with all the traditional sources that won't go away? Of course, there is always the risk that Little Data will be treated as a lesser breed, but its position has to be anchored in the world of Big Data to make sure humanists continue to appreciate the widest array of experiences.

From the outset, it should be clear that the discussion is about the conceptual impact of large databases and not just the Digital Humanities. A large component of the Digital Humanities deals with distribution, publication, and preservation, complex technical problems in their own right. What happens to data if it is preserved on outmoded technology? How can one create public portals to best interact with materials that have been painstakingly digitized $?^{24}$ These questions give birth to intricate projects that involve archivists, curators, library scientists, computer programmers, and others. Map collections, entire bodies of national literature, and archival documents have found their way onto websites, and the Internet Archive scours the web every day to preserve three-dimensional and digitally born materials. Many of these projects embody a primeval empirical urge, and though this urge, at its base positivistic, is worthy of contemplation, it remains but a stop on the longer journey that follows.

More philosophical issues, such as the emergence of an entity called digital time, will also be looked at. The connection between digital technologies and time may seem obscure but only because no attention has been paid to it. More often than not, the result of data crunching is presented in a timeless manner. Distant reading, for example, is almost entirely a spatial phenomenon. Yet the modern production of data has a critical time component. On the surface, the emergence of digital time confirms a Heideggerian critique-the present, das 'jetzt,' the nunc was becoming smaller and smaller because in sports, with its tenths of seconds, and in physics, with its millionths of seconds, the present was being reduced to 
the tiniest of fractions; and rather than gaining anything, humans in a technological age were losing time. ${ }^{25}$ Big Data has continued this trend and is as guilty as Heidegger suggests.

Time in the digital age is, however, much more complex and, like language, has to be understood in a longer sequence to grasp how the loss of the present is incidental to other factors that impact a postmodern depiction of time. At the end of the nineteenth century, intellectuals were dissatisfied with a Newtonian conception that put time on a rigid and immutable axis. Einstein's name easily comes to mind, as his theory of relativity situated time in a system of coordinates tied to the observer. Einstein's theory, though it is often presented otherwise, had no absolute connection with humans per se. The 'observer' was an occupier of certain coordinates rather than a flesh-and-blood human being with social and cultural proclivities that might impact his or her position in time; the story of the clocks at the train station only has meaning for someone who knows how to read an analog clock (not something to take for granted in a digital age).

Despite Einstein's indifference, other scholars sought to humanize time and give time a subjective quality. Henri Bergson in Duration and Simultaneity argued that each consciousness experienced duration on its own terms. ${ }^{26}$ While the philosophical idea of consciousness would be foreign to most postmodern thought, Bergson created a gap into which subjectivity could flow. Years later, Norbert Elias built on these premises, while pushing them in a different direction. Elias, who was more concerned with the social and disdainful of consciousness, argued that time was little more than a relationship. ${ }^{27}$ This social relationship had been its primary function until Galileo locked up time in his laboratory and used it as a raw measurement tool absent of any social function. All these trends encouraged twentieth-century postmodern thinkers to promote the endless subjectivity, whether individual or communal, of time.

Digital time in a world of Big Data could slip easily into this talk. It is not a function of the universe nor of the pulse of a quartz. Rather, it has conventional qualities determined by the individuals and organizations that regulate it. It would thereafter not be difficult to make claims about the high priests of the digital world and how they control time. Yet the repetition of this trope would inflict a substantial intellectual loss and shed no light on the fascinating nooks and crannies of digital time.

As an introduction, one can look at the centralizing function of digital time, a process of which Elias was aware within the context of the Industrial Revolution. Digital time has spread a uniform clock throughout the globe and created an identical time grid that localizes the farmer in Nebraska and the restaurateur in Inner Mongolia. It is not that they use the same timing system (the 24-hour clock), but that their times are identical. The centralizing and universalizing tendency of digital time is much closer to Kantian idealism than postmodern relativism. Lived 
experience follows an unspoken temporal imperative, and most contemporary research falls within this grid.

More intriguing aspects can be added. Consider the words that are regularly pulled from their initial textual setting and placed in databases. This practice is common amongst scholars who want to chart word usage over time, but most of these studies don't consider the temporal environment in which these terms existed. The original word was situated in a time environment determined by verb tenses and other sentence structures. All these time tags vanish when the word is placed in a database. Not only does the first time vanish, but the term is now surrounded by the time tags of the digital grid. Its original sense of time becomes fragmented by the digital order. Is there even such a thing as an original time in the digital milieu? How can the time embedded in Latin hexameter be preserved, or how is it altered, once these words enter a database? What would happen to Walter Benjamin's flâneur and the rhythms of that walker if he was drawn too deeply into the digital time frame? Fluid steps would surely become fragments. Similarly, will the ring of a grandfather clock be mere noise because it has no role in the digital world?

Time in this context has undergone enormous changes since the start of the twentieth century: fragmentation, relocation, re-adoption, and mutation from one digital application to the next make it an elusive character to follow. Readers of Proust's In Search of Lost Time know how artful time can be, and time is no less crafty today. Yet the parameters of digital time have a novel quality, such that this quality must be brought to light.

Not surprisingly, the advent of Big Data forces a rethinking of mysteries that have occupied philosophers since humans began to philosophize. Time belongs in the category of the mysterious, and so does the notion that seeing is believing. This last proverb expresses a direct link between the sense data received in the eyeball and its registration in the mind. In the worldview of the empiricist, most commonly associated with John Locke, we can only know and trust the information that arrives to us through the five senses, such as the sense data the eyeball perceives. If we begin with a tabula rasa, then the sense data fills our brains with ever increasing information from which we can learn. A chapter on data visuals explores this more closely.

Criticisms of Lockean empiricism began already with David Hume and Immanuel Kant, indicating the sense data approach had critics well before postmodernism. With their skeptical views, postmodernists naturally kept their distance from any neutral acquisition of knowledge but were, in particular, concerned to undermine the status of vision. ${ }^{28}$ Vision was so closely tied to observation and observation was so closely tied to the scientific method-therefore, the status of vision had to be dismantled. Moreover, vision was associated with truth and objectivityphotographs don't lie, because they record a moment in time.

Postmodernists therefore found creative ways to denounce vision. Three brief examples from three visual media-painting, photography, 
and film-make this point. At the start of The Order of Things, Foucault fascinated readers with his discussion on Velazquez's Las Meninas. ${ }^{29} \mathrm{He}$ developed the idea of a 'gaze.' The gaze did not collect objective knowledge, as the classic eyeball was supposed to do, but surveilled a situation to exert influence or establish subtle control. The gaze was much more than the physical act of seeing; the gaze was wrapped in a series of social codes. In Chambre claire, Roland Barthes looked beyond the sense data and wrote about the stadium, the cultural connotations clear in each photograph, and the punctum, which unbalances or abstracts the stadium and has an unregulated quality. ${ }^{30} \mathrm{On}$ film, Christian Metz argued against a "cult of the "visual"" that bordered "upon the irrational." 31 He preferred more discursive definitions of the visual.

The visual landscape has changed dramatically since these works were written. When Foucault wrote about the gaze, Americans were already watching massive amounts of television, but the learned community was still by and large textual. Moreover, even for television watchers, the intensely visual component of their day was over once the television was turned off. With the Internet and YouTube, so much more time is spent absorbing moving imagery; this global phenomenon is fascinating insofar as the preference for the visual tells us something about our biological selves. In the future, the learners who become professionals will have done so on a visual diet and will have a different attitude toward visuals. In a society filled with so many visual learners, the visual pessimism will lose its attraction.

Come what may, the continued production of quantified data will change much of this because the visual representation of data content has become such an integral component of visual experience. The nature of a database or Big Data is such that it must be displayed in a visually sophisticated manner. As such the presentation of knowledge is experiencing a visual revolution. Not long ago, visuals were the domain of art historians, but that has changed. Any humanist who chooses to use Big Data has to decide how to display it and thus select a mode of graphic expression; this step is unavoidable. The selection of a graphical mode of representation is not identical with eyewitnessing a crime scene, but the expanding presence of data and our interactions with it are not completely separate from the situations that agonized postmodern theorists. If a scholar is perfectly content to present factual data in a graph, how could that scholar simultaneously succumb to arguments about a gaze, since you cannot neatly 'gaze' at these graphs?

Historians used graphs in the past, but they tended to be rudimentary ones with simple X-Y axes and a single slanted line that indicated growth or decline. This tradition has little space in the world of Big Data because of the variables that need to be presented and the dynamic interactive manners being developed to convey information in digital projects such as those being developed with the support of Stanford University Press. The practice then is much closer to what Edward Tufte has been 


\section{Introduction}

studying over the past few decades, his favorite example being Charles Joseph Minard's statistical visualization of Napoleon's retreat from Russia. ${ }^{32}$ The trajectory present in Tufte's world introduces a likely future for the humanities, a future that must be understood now.

Visuals are already appearing in publications, offering a twist to Peter Burke's appeal for more visual material. ${ }^{33}$ The visuals are not traditional images but specially designed representations of knowledge that elicit intrigues. For example, viewers are becoming accustomed to seeing millions of bits of information aggregated into a few straight linesindividual items remain essentially invisible, but the lines vividly present conclusions at a general level. This might be considered distant viewing, a cousin to Moretti's concept. The selection of colors also becomes criti$\mathrm{cal}$ and opens doors to rethinking the social significance of these tones. The publication of knowledge in these instances reveals itself in a manner foreign to traditional textual forms.

The emerging abundance of data visuals has inherent complexities because it straddles two sides of a debate. On the one hand, these visuals are based on bits of strictly regulated and logically generated information. Few scholars evince grave epistemological concern about relying on such data. On the other hand, the best means to present the data has an aesthetic and artistic component that could overshadow the data itself. Unlike the rudimentary charts and line graphs of yesteryear or even the monochrome graphs on early computers, the dynamic possibilities of visuals, seen on a daily basis in publications such as the New York Times, add a layer of analysis. Soon the dominance of these visuals will further erode the authority of the linguistic turn.

Data visuals then are yet another realm where complacency and familiarity are unwelcome. For those who have worked with data visuals for decades, the discussion on visuals may be of less interest. Textual scholars will find much more to ponder since the same rules don't apply when reading a text as when looking at a graph. In fact, new skills are already being honed to cope with graphical representation. Tufte's promotion of objective truths in visual representations is a throwback to the days before postmodernism, but there are better alternatives to his stance than to rely on another throwback, postmodern anti-ocularism. If there is a middle ground, only further exploration will reveal it.

After three chapters focused on large data sets, the discussion moves on to the last and perhaps most intriguing issue, that of digital forgeries. The question of forgeries is multipronged. First, the notion of a forgery ties into the insecurities of the emerging digital universe. Fake news has already become a common expression, abetted by the Internet, social media, and the glut of data production. The website of the Foreign Ministry of the Russian Federation identifies what it considers fake news with a digital red stamp. Fake news and other elements in the post-truth world are not forgeries per se, but they demonstrate the need for extreme 
caution when looking at or listening to digital information. They suggest that a little more probing will reveal forgeries familiar to readers from more traditional times.

Forgeries have been a big part of postmodern thought because they link with efforts to undermine authorship and authenticity. When a forger creates a perfect copy of a Picasso, painting being a traditional realm for forgeries, how can one assert single authorship if one cannot identify who the author is? The postmodernist strategy was to seize upon the little window of doubt that opens when one cannot be certain that one is looking at an original. There are no objective standards to judge its status, and therefore what should be easy to determine as the fact of the matter becomes a matter of convention. The next step is to route the forgery through the linguistic turn and make the forgery (or original) answer only to discursive evidence. This intellectual trajectory is hardly surprising and therefore worth investigating once it arrives in a digital environment.

Traditional forgeries are not that difficult to conjure. We talk about forged signatures, forged letters, and, in famous cases, forged works of art. In the 1930s, Han van Meegeren fooled the art world with his forgeries of Johannes Vermeer. Digital forgeries are more problematic because they defy straightforward categorization. One can forge a digital signature, but what would it look like to forge a digital artwork? Could one forge a digital correspondence or add an e-mail to an existing correspondence? Could one completely forge a massive database and place it in some dark corner of the web with the hope that a naïve researcher will seize upon it two decades down the road? With all these dizzying questions, the parameters of digital forgery are not even clear.

Nevertheless, opening a discussion on digital forgeries sets up possibilities. The first task is to define digital forgeries relative to traditional ones and develop an instinct for identifying novelty over tradition. Once this has been established, the discussion can move onto more philosophical ground because outside of auction houses, forgery quickly becomes a philosophical issue. Rudolf Arnheim and Nelson Goodman provided their thoughts on forgery in the heart of the postmodern period. ${ }^{34}$ Carlo Ginzburg, a microhistorian fascinated by small traces, looked at forgeries from a more empirical perspective. ${ }^{35}$ Juxtaposing their insights with digital possibilities indicates, if only lightly, how to proceed with digital forgeries. Thereafter, the discussion turns to the process of identifying forgeries. This process was critical for Ginzburg, who insisted on visual identification and reminded his readers of Sherlock Holmes's magnifying glass, perhaps a precursor to the digital zoom function. Identifying digital forgeries is altogether different, however; the zoom function has only a few commonalities with a magnifying glass. Once again, identification will depend upon characteristics that lie below the surface. Much like art connoisseurs rely on chemical analyses to date painting materials, 


\section{Introduction}

analysts will consult with computer programmers to get at the digital layer that lies below the forgery itself. This process brings logic and binaries back into the world of the humanist, but in a mystifying way that requires some form of revelation. Digital forgeries are often contiguous with postmodern experience, but one must note where they go their separate ways.

All the previous comments should not give the mistaken impression postmodernists were blind to technological developments; on the contrary, they belong to a long line of discontents. From the physical destruction of the Luddites in the nineteenth century or Heideggerian nostalgia for undammed rivers in the German Middle Ages, postmodernists have their antecedents. For postmodernists, regimes of technology became a stock phrase with which to criticize modern times. Nor can it be said that the postmodernists' technological pessimism precedes the modern computer as could be said of Heidegger's. In the early 1990s, Gilles Deleuze associated computers with social control and excited his followers with new ways to denounce what others saw as progress. ${ }^{36}$

These postmodern technological critiques were done from a distance before humanistic scholarship was fully immersed in the technological world, before Digital Humanities became the cutting edge of research (and sharp edges are designed to be divisive). In the 1970s, it was still possible to remain aloof from or indifferent to technologies and to treat technology as discursive rather than personally invasive. Nowadays scholars are enmeshed in them in deeper and deeper ways. At a casual level, scholars interact with them when shopping groceries, buying shoes, or having Netflix or Amazon suggest additional viewing pleasures. Professionally, algorithms and their fruit have embedded themselves in the methodologies of so many disciplines, it has become impossible to avoid them.

A well-paved path is preferred by those with thin soles, but it does not make much sense to repurpose these older critiques for every new technological development; can we imagine regurgitating these phrases on technologies that lie fifty or a hundred years in the future? Surely they will run out of gas at some point. If we don't do otherwise, and this is the main point, we will be dealing with ideas that have taken on the air of truths. The only subsequent step from there leads to stagnation. When so many new adventures lie ahead, why seek the security of old friends? We will find ourselves like the narrator at the end of Proust's A La Recherche, who enters a salon only to see how all his friends have aged; it takes him a while to realize that he has grayed as well.

Evidently, this transition has to be grappled with and accepted in the world of humanist research. Acceptance, however, does not imply capitulation if capitulation is to be understood as a complete transition to quantitative analysis. It does imply taking a strenuous look at how to preserve the irregular, emotional, aesthetic, humane, and qualitative aspects of the humanist tradition without assuming that nothing has really changed 
over the last fifty years. Methods will adapt dramatically and, as a consequence, reconsiderations of the postmodern canon will become the norm. This is not a rejection of this canon but an awareness that the time has come to move on. What follows takes us forward, and even if some basic avenues will be laid, it is still too early to tell where we will land. But this uncertainty, such a charmed word amongst postmodernists, has to be welcomed for what it might bring.

\section{Notes}

1. Allan Bloom, The Closing of the American Mind (New York: Simon and Schuster, 1988).

2. Matthew K. Gold and Lauren F. Klein, eds., Debates in the Digital Humanities 2016 (Minneapolis and London: University of Minnesota Press, 2016). Lara Putnam writes about a "discipline's epistemology." See Lara Putnam, "The Transnational and the Text-Searchable: Digitized Sources and the Shadows They Cast," American Historical Review 121 (April 2016): 379.

3. David J. Bodenhamer, "The Spatial Humanities: Space, Time and Place in the New Digital Age," in History in the Digital Age, ed. Toni Weller (London and New York: Routledge, 2013), 34.

4. Kwong Bor Ng, Jason Kucsma, and Metropolitan New York Library Council, eds., Digitization in the Real World: Lessons Learned From Small and Medium-Sized Digitization Projects (New York: Metropolitan New York Library Council, 2010), xi.

5. Johanna Drucker, "Humanistic Theory and Digital Scholarship," in Debates in the Digital Humanities (Minneapolis: University of Minnesota Press, 2012), 86 .

6. Gayatri Chakravorty Spivak, "Afterword," in Of Grammatology, edited by Jacques Derrida (Baltimore: Johns Hopkins University Press, 2016).

7. Arthur C. Danto, After the End of Art: Contemporary Art and the Pale of History, The A.W. Mellon Lectures in the Fine Arts 1995 (Princeton, NJ: Princeton University Press, 1997), 111.

8. Isaiah Berlin, Historical Inevitability, Auguste Comte Memorial Trust Lecture 1 (London: Oxford University Press, 1954).

9. Thomas Kuhn, The Structure of Scientific Revolutions (Chicago: University of Chicago Press, 1962).

10. James Bryant Conant, On Understanding Science: An Historical Approach (New Haven: Yale University Press; London: G. Cumberlege, Oxford University Press, 1947); Steven Shapin and Simon Schaffer, Leviathan and the AirPump: Hobbes, Boyle, and the Experimental Life (Princeton, NJ: Princeton University Press, 1989).

11. Drucker, "Humanistic Theory and Digital Scholarship."

12. Hayden V. White, Metahistory: The Historical Imagination in NineteenthCentury Europe (Baltimore: Johns Hopkins University Press, 1973).

13. Johann Gottfried Herder, Abhandlung über den Ursprung der Sprache (Stuttgart: Reclam, 1969).

14. Franco Moretti, Distant Reading (London: Verso, 2013).

15. Ludwig Wittgenstein, Tractatus Logico-philosophicus (London and New York: Routledge \& Paul, 1961). The Philosophical Investigations does not bound experience with language at all.

16. Chris Anderson, "The End of Theory: The Data Deluge Makes the Scientific Method Obsolete," WIRED, accessed April 24, 2018, www.wired.com/2008/ 06/pb-theory/. 


\section{Introduction}

17. For a dissenting view, see the introduction in Michael N. Jones, ed., Big Data in Cognitive Science (New York, NY: Routledge, 2017). See also Patrik Svensson and David Theo Goldberg, eds., Between Humanities and the Digital (Cambridge, MA: The MIT Press, 2015).

18. Quentin Skinner, ed., The Return of Grand Theory in the Human Sciences (Cambridge and New York: Cambridge University Press, 1990).

19. Anderson, "The End of Theory."

20. Safiya Umoja Noble, Algorithms of Oppression: How Search Engines Reinforce Racism (New York: New York University Press, 2018).

21. On the algorithm as a black box, see Frank Pasquale, The Black Box Society: The Secret Algorithms That Control Money and Information (Cambridge, MA and London: Harvard University Press, 2015).

22. "Eric Schmidt: Every 2 Days We Create as Much Information as We Did Up to 2003," TechCrunch (blog), accessed September 25, 2019, http://social. techcrunch.com/2010/08/04/schmidt-data/.

23. Steve Lohr, “The Origins of 'Big Data': An Etymological Detective Story," Bits Blog (blog), February 1, 2013, https://bits.blogs.nytimes.com/2013/02/01/ the-origins-of-big-data-an-etymological-detective-story/.

24. Roy Rosenzweig, Clio Wired: The Future of the Past in the Digital Age (New York: Columbia University Press, 2011). These issues have been discussed for at least twenty years. See John H. Whaley, Jr., "Digitizing History," The American Archivist 57, no. 4 (Fall 1994): 660-72. Most recently, see Ian Milligan, History in the Age of Abundance? How the Web Is Transforming Historical Research (Montreal and Kingston: McGill-Queen's University Press, 2019).

25. Martin Heidegger, Was heisst Denken? (Frankfurt am Main: Vittorio Klostermann, 2002), 104.

26. Henri Bergson, Duration and Simultaneity: With Reference to Einstein's Theory (Indianapolis: Bobbs-Merrill, 1965).

27. Norbert Elias, Time: An Essay (Oxford: B. Blackwell, 1992).

28. See Martin Jay, Downcast Eyes: The Denigration of Vision in TwentiethCentury French Thought (Berkeley: University of California Press, 1993).

29. Michel Foucault, Les mots et les choses: Une archéologie des sciences bumaines (Paris: Gallimard, 1990).

30. Roland Barthes, La chambre claire: Note sur la photographie (Paris: Cahiers du cinéma, 1980).

31. Christian Metz, Language and Cinema, vol. 26 (The Hague: Mouton, 1974), 34.

32. Edward R. Tufte, Beautiful Evidence (Cheshire, CT: Graphics Press, 2006).

33. Peter Burke, Eyewitnessing: The Uses of Images as Historical Evidence, Picturing History Series (Ithaca, NY: Cornell University Press, 2001).

34. Their essays appear in Denis Dutton, ed., The Forger's Art: Forgery and the Philosophy of Art (Berkeley: University of California Press, 1983).

35. Carlo Ginzburg, "Clues: Roots of an Evidential Paradigm," in Clues, Myths, and the Historical Method (Baltimore: Johns Hopkins University Press, 1989).

36. Gilles Deleuze, "Postscript on the Societies of Control," October 59 (1992): 3-7. 


\section{References}

1. Shirley Lindenbaum and Margaret M. Lock, eds., Knowledge, Power, and Practice: The Anthropology of Medicine and Everyday Life, Comparative Studies of Health Systems and Medical Care (Berkeley: University of California Press, 1993).

2. Edward Hallett Carr, What Is History? (New York: Vintage Books, 1961), 10-11.

3. Francis Fukuyama, The End of History and the Last Man (New York: Free Press, 1992).

4. Michel Foucault, The Order of Things: An Archaeology of the Human Sciences (New York: Vintage Books, 1970), 324-5.

5. Bent Hamer, Kitchen Stories (2003).

6. Richard Rorty, Philosophy and the Mirror of Nature (Princeton, NJ: Princeton University Press, 1980), 139.

7. Richard Rorty, Jerome B. Schneewind, and Quentin Skinner, eds., Philosophy in History: Essays on the Historiography of Philosophy (Cambridge [Cambridgeshire] and New York: Cambridge University Press, 1984).

8. Ian Hacking, The Emergence of Probability: A Philosophical Study of Early Ideas About Probability, Induction and Statistical Inference, 2nd ed. (Cambridge and New York: Cambridge University Press, 2006).

9. Richard Rorty, Eine Kultur obne Zentrum : Vier Philosophische Essays und ein Vorwort (Stuttgart: Reclam, 1993).

10. Marshall Sahlins, Islands of History (Chicago: University of Chicago Press, 1985).

11. On his philosophical background, see Clifford Geertz, Available Light: Anthropological Reflections on Philosophical Topics (Princeton, NJ: Princeton University Press, 2000).

12. Dipesh Chakrabarty, Provincializing Europe: Postcolonial Thought and Historical Difference (Princeton, NJ: Princeton University Press, 2000), 250.

13. Chakrabarty, Provincializing Europe, 251.

14. Gayatri Chakravorty Spivak, "Can the Subaltern Speak?" in Marxism and the Interpretation of Culture, ed. Cary Nelson and Lawrence Grossberg (Urbana: University of Illinois Press, 1988), 279-313.

15. Spivak, "Can the Subaltern Speak?" 297.

16. Spivak, "Can the Subaltern Speak?" 301.

17. Spivak, "Can the Subaltern Speak?" 281. In a recent version, Spivak writes, "I have some accident-of-birth facility there."

18. Gayatri Chakravorty Spivak, "Can the Subaltern Speak?" in Can the Subaltern Speak? Reflections on the History of an Idea, ed. Rosalind C. Morris (New York: Columbia University Press, 2010), 56.

19. For more details on the project, see Peter Novick, That Noble Dream: The "Objectivity Question" and the American Historical Profession (Cambridge: Cambridge University Press, 1988), 526-35.

20. Foucault had interests in medicine but was less focused on physics, chemistry, math, and similar scientific fields. See Michel Foucault, The Birth of the Clinic: An Archaeology of Medical Perception (New York: Pantheon Books, 1973).

21. James Bryant Conant, On Understanding Science: An Historical Approach, The Terry Lectures (New Haven and London: Yale University Press, 1947).

22. See the preface to Kuhn, The Structure of Scientific Revolutions.

23. Shapin and Schaffer, Leviathan and the Air-Pump.

24. Jessica Riskin, Science in the Age of Sensibility: The Sentimental Empiricists of the French Enlightenment (Chicago: University of Chicago Press, 2002). 
25. William E. Burns, The Scientific Revolution in Global Perspective (New York: Oxford University Press, 2016), 18, 35-6.

26. William Newman, "A Preliminary Reassessment of Newton's Alchemy," in Cambridge Companion to Newton (Cambridge: Cambridge University Press, 2016), 455-6.

27. Newman, "A Preliminary Reassessment of Newton's Alchemy," 463.

28. Alan D. Sokal, ed., The Sokal Hoax: The Sham That Shook the Academy (Lincoln: University of Nebraska Press, 2000).

29. Kenneth Hewitt, "Excluded Perspectives in the Social Construction of Disaster," in What Is a Disaster? Perspectives on the Question, ed. E. L. Quarantelli (London and New York: Routledge, 1998), 75-92.

30. Rebecca Skloot, The Immortal Life of Henrietta Lacks (New York: Crown Publishers, 2010). The information on Lacks comes from this volume.

31. Michel Foucault and Colin Gordon, Power/Knowledge: Selected Interviews and Other Writings, 1972-1977, 1st American ed. (New York: Pantheon Books, 1980), 51.

32. Foucault and Gordon, Power/Knowledge, 51.

33. Patricia Hill Collins, Black Feminist Thought: Knowledge, Consciousness, and the Politics of Empowerment (New York: Routledge, 2000), 251-72.

34. Patricia Hill Collins, "Learning From the Outsider Within: The Sociological Significance of Black Feminist Thought," Social Problems 33, no. 6 (1986): S14-S32, https://doi.org/10.2307/800672.

35. Isabel Wilkerson, The Warmth of Other Suns: The Epic Story of America's Great Migration (New York: Random House, 2010).

36. Paul De Kruif, Microbe Hunters (San Diego: Harcourt, Inc, 1996).

37. Drucker, "Humanistic Theory and Digital Scholarship," 90.

38. Drucker, "Humanistic Theory and Digital Scholarship," 92-3.

39. Drucker, "Humanistic Theory and Digital Scholarship," 86.

1. Johann Gottfried Herder, Abhandlung über den Ursprung der Sprache (Stuttgart: Reclam, 1969).

2. Gottlob Frege, The Foundations of Arithmetic: A Logico-Mathematical Enquiry Into the Concept of Number (New York: Philosophical Library, 1950).

3. Rorty, Philosophy and the Mirror of Nature, 8.

4. Richard Rorty, The Linguistic Turn: Recent Essays in Philosophical Method (Chicago: University of Chicago Press, 1967).

5. Martin Heidegger, "Der Weg zur Sprache," in Unterwegs zur Sprache (Frankfurt am Main: Vittorio Klostermann, 1985).

6. Jacques Derrida, Margins of Philosophy, trans. Alan Bass (Chicago: University of Chicago Press, 1982).

7. Gabrielle M. Spiegel, The Past as Text: The Theory and Practice of Medieval Historiography, Parallax (Baltimore: Johns Hopkins University Press, 1997), xix.

8. Gabrielle M. Spiegel, "History, Historicism, and the Social Logic of the Text," in The Past as Text: The Theory and Practice of Medieval Historiography, Parallax (Baltimore: Johns Hopkins University Press, 1997), 27.

9. Spiegel, The Past as Text: The Theory and Practice of Medieval Historiography, 177.

10. Dominick LaCapra, History and Reading: Tocqueville, Foucault, French Studies (Toronto and Buffalo: University of Toronto Press, 2000), 52.

11. Foucault, The Order of Things, 286-9.

12. Allan Megill, Prophets of Extremity: Nietzsche, Heidegger, Foucault, Derrida (Berkeley: University of California Press, 1985), 238. 
13. Antoine Prost, Republican Identities in War and Peace: Representations of France in the Nineteenth and Twentieth Centuries, The Legacy of the Great War (Oxford and New York: Berg, 2002); Stephen Kotkin, Magnetic Mountain: Stalinism as a Civilization (Berkeley: University of California Press, 1995).

14. White, Metahistory.

15. Leonard Bernstein, Leonard Bernstein at Harvard: "The Unanswered Question,” Norton Lectures 1973, videorecording (Kultur, 1992), 15-16.

16. Bernstein, Leonard Bernstein at Harvard, 29.

17. Bernstein, Leonard Bernstein at Harvard, 15-16.

18. Bodenhamer, "The Spatial Humanities."

19. Arthur C. Danto, Analytical Philosophy of History (Cambridge: Cambridge University Press, 1965).

20. Arthur C. Danto, The Transfiguration of the Commonplace: A Philosophy of Art (Cambridge, MA: Harvard University Press, 1981), 82.

21. Danto, The Transfiguration of the Commonplace, 176.

22. Steven Pinker, The Stuff of Thought: Language as a Window Into Human Nature (New York: Viking, 2007).

23. Kotkin, Magnetic Mountain. See also Stephen E. Hanson, Time and Revolution: Marxism and the Design of Soviet Institutions (Chapel Hill, NC: University of North Carolina Press, 1997).

24. Chakrabarty, Provincializing Europe.

25. Bernard Comrie, "Causative Verb Formation and Other Verb-Deriving Morphology," in Grammatical Categories and the Lexicon, ed. Timothy Shopen, vol. III, Language Typology and Syntactic Description (Cambridge: Cambridge University Press, 1985), 309-48.

26. Moretti, Distant Reading.

27. Martin Jay, "In the Realm of the Senses: An Introduction," The American Historical Review 116, no. 2 (2011): 309.

28. Henry Staten, Wittgenstein and Derrida (Lincoln and London: University of Nebraska Press, 1984).

29. Heidegger wrote: "über die Sprache sprechen ist vermutlich noch schlimmer als über das Schweigen schreiben." Martin Heidegger, "Die Sprache," in Unterwegs zur Sprache (Frankfurt am Main: Vittorio Klostermann, 1985), 10.

30. R. Murray Schafer, Voices of Tyranny, Temples of Silence (Arcana Editions, 1993), 9.

31. Schafer, Voices of Tyranny, Temples of Silence, 57.

32. Schafer, Voices of Tyranny, Temples of Silence, 49.

33. Schafer, Voices of Tyranny, Temples of Silence, 47.

34. Schafer, Voices of Tyranny, Temples of Silence, 51.

35. Schafer, Voices of Tyranny, Temples of Silence, 15.

36. Friedrich Nietzsche, "Die Philosophie im tragischen Zeitalter der Griechen," in Werke in drei Bänden (München: Carl Hanser, 1966), 391.

37. Ludwig Wittgenstein, Philosophical Investigations, ed. G. E. M. Anscombe, 3rd ed. (Oxford and Malden, MA: Blackwell, 2001), 31.

38. Wittgenstein, Philosophical Investigations, 66.

39. Quoted in Ginzburg, "Clues: Roots of an Evidential Paradigm," 108.

40. Heidegger, "Die Sprache," 26-7.

41. Mark S. R. Jenner, "Follow Your Nose? Smell, Smelling, and Their Histories," The American Historical Review 116, no. 2 (April 2011): 335-51.

42. Jay, "In the Realm of the Senses," 309.

43. Jay, Downcast Eyes, 591. 
44. John Berger, Ways of Seeing (London: British Broadcasting Corp.; New York: Penguin Books, 1972).

45. Berger, Ways of Seeing, 28.

46. Marcel Proust, Du côté de chez Swann (Paris: Gallimard, 1987), 46-7.

47. Marcel Proust, Le Temps retrouvé (Paris: Gallimard, 1992).

48. Proust, Le Temps retrouvé, 232.

49. Proust, Le Temps retrouvé, 232. The French is a "vue optique des années."

50. Wolfgang Schivelbusch, Disenchanted Night: The Industrialization of Light in the Nineteenth Century (Berkeley: University of California Press, 1995).

51. George Kennan, Tent Life in Siberia (Salt Lake City: Peregrine Smith Books, 1986), 329-30.

52. Heidegger, "Die Sprache," 9.

53. Burke, Eyewitnessing.

54. Even if there were grammatical changes, most researchers don't bother to find out.

55. Wittgenstein, Philosophical Investigations, 366. "Imponderable evidence includes subtleties of glance, of gesture, of tone."

56. Alain Corbin, Village Bells: Sound and Meaning in the 19th-Century French Countryside, European Perspectives (New York: Columbia University Press, 1998).

57. Tim Harte, "Stalinism's Sights and Smells in the Films of Aleksei German, Sr.," in Russian History Through the Senses: From 1700 to the Present, ed. Matthew P. Romaniello and Tricia Starks (London: Bloomsbury Academic, an imprint of Bloomsbury Publishing Plc, 2016).

58. Gerhard Paul and Ralph Schock, eds., Sound der Zeit: Geräusche, Töne, Stimmen; 1889 bis heute (Göttingen: Wallstein, 2014).

59. Wolfgang Krischke, "Sprachwissenschaft: Altbewährtes frischgemacht," Frankfurter Allgemeine, May 10, 2018, www.faz.net/aktuell/feuilleton/hochschule/digital-humanities-eine-bilanz-1-6-sprachwissenschaft-15579104. html. See, for example, Hans-Martin Gauger and Herbert Heckmann, Wir sprechen anders: Warum Computer nicht sprechen können: Eine Publikation der Deutschen Akademie für Sprache und Dichtung (Frankfurt am Main: Fischer, 1988).

60. The study of translation has its own history in analytic philosophy. As one example, see Donald Davidson, "Indeterminism and Antirealism," in Subjective, Intersubjective, Objective (Oxford and New York: Oxford University Press, 2001), 69-84.

61. Willard Van Orman Quine, Word and Object (Cambridge: Technology Press of the Massachusetts Institute of Technology, 1960).

1. Berlin, Historical Inevitability, 3. There is, in fact, a postmodern equivalent. Many researchers have never read Foucault but, in one way or another, continue to promote his ideas. In Peter Novick's book, Comte is not in the index but positivism comes up all over the place. See Novick, That Noble Dream.

2. Auguste Comte, The Positive Philosophy of Auguste Comte, trans. Harriet Martineau, vol. II (London: G. Bell and Sons, 1896), 211.

3. Comte, The Positive Philosophy of Auguste Comte, II:212.

4. Comte, The Positive Philosophy of Auguste Comte, II:216.

5. His attitude is not surprising given how long it took to demonstrate the validity of Newton's theorems. See Thomas S. Kuhn, "The Function of Measurement in Modern Physical Science," Isis 52, no. 2 (June 1961): 161-93.

6. Mike Gane, Auguste Comte, Key Sociologists (London and New York: Routledge, 2006), 61.

7. Auguste Comte, The Positive Philosophy of Auguste Comte, trans. Harriet Martineau, vol. I (London: G. Bell and Sons, 1896), 17. On this as a general 
trend, see other comments in Mike Gane, Auguste Comte, Key Sociologists (London and New York: Routledge, 2006).

8. Comte, The Positive Philosophy of Auguste Comte, II:219.

9. Comte, The Positive Philosophy of Auguste Comte, II:230.

10. Comte, The Positive Philosophy of Auguste Comte, I:166.

11. Leopold von Ranke, "On the Character of Historical Science (a Manuscript of the 1830's)," in The Theory and Practice of History, ed. Georg G. Iggers (London and New York: Routledge, 2011), 15.

12. Charles A. Beard, "That Noble Dream," The American Historical Review 41, no. 1 (October 1935): 86.

13. Leopold von Ranke, "On Progress in History (From the First Lecture to King Maximilian II of Bavaria 'On the Epochs of Modern History,' 1854)," in The Theory and Practice of History, ed. Georg G. Iggers (London and New York: Routledge, 2011), 22.

14. Leopold von Ranke, "Pitfalls of a Philosophy of History (Introduction to a Lecture on Universal History; a Manuscript of the 1840's)," in The Theory and Practice of History, ed. Georg G. Iggers (London and New York: Routledge, 2011), 19.

15. Wilhelm Dilthey, Introduction to the Human Sciences, vol. 1 (Princeton, NJ: Princeton University Press, 1989), 57, 75.

16. Dilthey, Introduction to the Human Sciences, 99.

17. Dilthey, Introduction to the Human Sciences, 140.

18. Georg G. Iggers, The German Conception of History: The National Tradition of Historical Thought From Herder to the Present (Middletown, CT: Wesleyan University Press, 1983), 134-5.

19. Dilthey, Introduction to the Human Sciences, 78.

20. Dilthey, Introduction to the Human Sciences, 141.

21. Dilthey, Introduction to the Human Sciences, 142.

22. Iggers, The German Conception of History, 138.

23. Friedrich Nietzsche, "Zur Genealogie der Moral," in Werke in Drei Bänden, vol. II (Muenchen: Hanser Verlag, n.d.), 790. In English, "the doer is merely a fiction added to the deed-the deed is everything." This is Walter Kaufmann's translation.

24. Michel Foucault, "Nietzsche, Genealogy, History," in The Foucault Reader, ed. Paul Rabinow, 1st ed. (New York: Pantheon Books, 1984), 80.

25. Martin Heidegger, "Nietzsches Wort 'Gott ist tot,'” in Holzwege (Frankfurt am Main: V. Klostermann, 1950), 209-10.

26. Arthur C. Danto, Nietzsche as Philosopher (New York: Columbia University Press, 2005), 83.

27. Quoted in Maudemarie Clark, Nietzsche on Truth and Philosophy, Modern European Philosophy (Cambridge and New York: Cambridge University Press, 1990), 104. Peter Berkowitz offered his readers the exact same excerpt to make a similar point. See Peter Berkowitz, Nietzsche: The Ethics of an Immoralist, 1st Harvard University Press pbk. ed. (Cambridge, MA: Harvard University Press, 1996), 10.

28. Quoted in Clark, Nietzsche on Truth and Philosophy, 105.

29. Megill, Prophets of Extremity, 54-5.

30. Martin Heidegger, "Science and Reflection," in The Question Concerning Technology and Other Essays, trans. William Lovitt (New York: Harper Perennial, 2013), 158-60.

31. Heidegger, "Science and Reflection," 165.

32. Heidegger, "Science and Reflection," 169-70.

33. Heidegger, "Science and Reflection," 163.

34. Heidegger, "Science and Reflection," 166-7. 
35. Martin Heidegger, Being and Time, trans. John Macquarrie and Edward Robinson (London: SCM Press, 1962), 214. For this discussion in visual terms, see Jay, Downcast Eyes, 270-1.

36. Heidegger, Being and Time, 216.

37. Quoted in Megill, Prophets of Extremity, 195.

38. Jacques Derrida, Limited Inc (Evanston, IL: Northwestern University Press, 1988).

39. Robert William Fogel and Geoffrey Rudolph Elton, Which Road to the Past? Two Views of History (New Haven: Yale University Press, 1983), 126.

40. This is a chapter title in Of Grammatology.

41. Jacques Derrida, Of Grammatology, trans. Gayatri Chakravorty Spivak (Baltimore: Johns Hopkins University Press, 2016), 81.

42. The French 'trace' is not the same as the English 'trace.' It can also be noted that Heidegger's Weg is a completely different invocation from Wittgenstein when he writes about a Wegweiser.

43. Judith Butler, "Introduction," in Of Grammatology, edited by Jacques Derrida, trans. Gayatri Chakravorty Spivak (Baltimore: Johns Hopkins University Press, 2016), X. The trace in Of Grammatology is primarily presented as a linguistic phenomenon though Derrida does link it to gesture in a slightly modified form. See Derrida, Of Grammatology, 255.

44. Spivak, "Afterword."

45. Brian Fung, "If You Search Google Maps for the N-Word, It Gives You the White House," Washington Post, May 19, 2015, www.washingtonpost. com/news/the-switch/wp/2015/05/19/if-you-search-google-maps-for-the-nword-it-gives-you-the-white-house/.

1. Martin Erwig, Once Upon an Algorithm: How Stories Explain Computing (Cambridge, MA: The MIT Press, 2017), 17. In the context of the current discussion, this book is fascinating because the author has made an extreme effort to employ postmodern terminology yet advocates a method completely at odds with postmodernism. As presented, the two approaches are impossible to reconcile.

2. Ed Finn, What Algorithms Want: Imagination in the Age of Computing (Cambridge, MA: MIT Press, 2017), 19. A variant of this theme appears in Arlindo L. Oliveira, The Digital Mind: How Science Is Redefining Humanity (Cambridge, MA: The MIT Press, 2017). Oliveira asks, what is the set of roads with [the] shortest total length that will keep all the cities connected?

3. See the opening page of Martin Heidegger, Holzwege (Frankfurt am Main: V. Klostermann, 1950). The title has been translated as "Off the Beaten Track" but this is rather misleading. The German original has wood/forest in the title; the material substance is critical to Heidegger's meaning and materiality resurfaces throughout the volume. The translation also suggests what the Holzwege were not rather than what they were. True, they were not the main roads; but they were paths, and they were beaten by the soft soles of individuals who really knew their forest environment. See Martin Heidegger, Off the Beaten Track, ed. Julian Young and Kenneth Haynes (Cambridge and New York: Cambridge University Press, 2002).

4. Finn, What Algorithms Want, 5.

5. This reference appears in Finn but relies on the work of Wendy Chun. See Wendy Hui Kyong Chun, Programmed Visions: Software and Memory (Cambridge, MA: MIT Press, 2011).

6. See the title heading to chapter one in Katherine Hayles, My Mother Was a Computer: Digital Subjects and Literary Texts (Chicago: University of Chicago Press, 2005). 
7. Pedro Domingos, The Master Algorithm: How the Quest for the Ultimate Learning Machine Will Remake Our World (New York, NY: Basic Books, 2015), 47.

8. Noble, Algorithms of Oppression, 10.

9. Tarleton Gillespie, "The Relevance of Algorithms," in Media Technologies: Essays on Communication, Materiality, and Society, ed. Tarleton Gillespie, Pablo J. Boczkowski, and Kirsten A. Foot (Cambridge, MA: The MIT Press, 2014), 169.

10. Gillespie, "The Relevance of Algorithms," 179.

11. James Grimmelmann, “The Google Dilemma," New York Law School Law Review 53 (September 2008): 944.

12. Pasquale, The Black Box Society, 3.

13. Erwig, Once Upon an Algorithm, 162.

14. Erwig, Once Upon an Algorithm, 162.

15. Erwig, Once Upon an Algorithm, 145.

16. Erwig, Once Upon an Algorithm, 75.

17. Erwig, Once Upon an Algorithm, 92.

18. Erwig, Once Upon an Algorithm, 182.

19. Erwig, Once Upon an Algorithm, 51, 145, 181, emphasis in original.

20. Erwig, Once Upon an Algorithm, 54.

21. Quine, Word and Object, 27.

22. For a more philosophical perspective, see John R. Searle, "Minds, Brains, and Programs," Behavioral and Brain Sciences 3, no. 3 (1980): 417-57.

23. Ludwig Wittgenstein, Philosophical Investigations, ed. G. E. M. Anscombe, 3rd ed. (Oxford and Malden, MA: Blackwell, 2001), 87. Der Wegweiser ist in Ordnung-wenn er, unter normalen Verhältnissen, seinen Zweck erfüllt.

24. Rudolf Carnap, The Logical Structure of the World, trans. Rolf A. George (Berkeley, CA: University of California Press, 1967).

25. Noble, Algorithms of Oppression, 9.

26. Finn, What Algorithms Want, 27.

27. Elias Muhanna, "Islamic and Middle East Studies and the Digital Turn," in The Digital Humanities and Islamic \& Middle East Studies (Berlin and Boston: De Gruyter, 2016), 9.

28. Muhanna, "Islamic and Middle East Studies and the Digital Turn," 230.

29. Alfred H. Conrad and John Robert Meyer, The Economics of Slavery: And Other Studies in Econometric History (Chicago: Aldine Pub. Co, 1964).

30. John Komlos, The Habsburg Monarchy as a Customs Union: Economic Development in Austria-Hungary in the Nineteenth Century (Princeton, NJ: Princeton University Press, 1983).

31. See James Cheshire and Oliver Uberti, Where the Animals Go: Tracking Wildlife With Technology in 50 Maps and Graphics (New York: W. W. Norton \& Company, 2017).

32. Robert A. Sobieszek, Ghost in the Shell: Photography and the Human Soul, 1850-2000: Essays on Camera Portraiture (Los Angeles: Los Angeles County Museum of Art; Cambridge, MA: MIT Press, 1999), 40-1.

33. Sobieszek, Ghost in the Shell.

34. Jordan Ellenberg, "Opinion: How Computers Turned Gerrymandering Into a Science," The New York Times, October 6, 2017, sec. Opinion, www.nytimes. com/2017/10/06/opinion/sunday/computers-gerrymandering-wisconsin. html.

35. These discussions abound amongst Digital Humanists and are well represented in the Debates in the Digital Humanities volumes. See Matthew K. Gold, ed., Debates in the Digital Humanities (Minneapolis: University of Minnesota Press, 2012). 
36. Cheshire and Uberti, Where the Animals Go, 160.

37. Mara Hvistendahl, "In China, a Three-Digit Score Could Dictate Your Place in Society," WIRED, accessed July 2, 2018, www.wired.com/story/age-ofsocial-credit/.

38. Muhanna, "Islamic and Middle East Studies and the Digital Turn," 171.

1. Rosenzweig, Clio Wired, 217.

2. Rosenzweig, Clio Wired, 5.

3. See, for example, Clifford B. Frith, Charles Darwin's Life With Birds: His Complete Ornithology (New York, NY: Oxford University Press, 2016), 60-2.

4. Francis Galton, Hereditary Genius: An Inquiry Into Its Laws and Consequences (London: Macmillan and Co, 1869).

5. Rebecca M. Lemov, Database of Dreams: The Lost Quest to Catalog Humanity (New Haven and London: Yale University Press, 2015).

6. Putnam, "The Transnational and the Text-Searchable: Digitized Sources and the Shadows They Cast," 378.

7. Bodenhamer, "The Spatial Humanities," 31.

8. www.digitalpanopticon.org

9. Lucy Williams and Barry Godfrey, "Bringing the Prisoner Into View: English and Welsh Census Data and the Victorian Prison Population," Australian Historical Studies 47, no. 3 (September 2016): 398-413.

10. For archival criticisms of the Internet Archive, see Rebecca Guenther and Leslie Myrick, "Archiving Web Sites for Preservation and Access: MODS, METS, and MINERVA," in Archives and the Digital Library, ed. William E. Landis and Robin L. Chandler (Binghamton, NY: Haworth Information Press, 2006), 141-66.

11. Since technologies can change, the information can be lost. The decay is a function of neglect and not of the passage of time. The information can simply disappear rather than decay.

12. Story by Bianca Bosker, "Why Everything Is Getting Louder," The Atlantic, November 2019, www.theatlantic.com/magazine/archive/2019/11/theend-of-silence/598366/.

13. Carr, What Is History.

14. Nietzsche had a similar attitude with respect to thought: “dass es zum Denken einer Technik, eines Lehrplans, eines Willens zur Meisterschaft bedarf,—dass Denken gelernt sein will, wie Tanzen gelernt sein will, als eine Art Tanzen.” Friedrich Nietzsche, "Götzendämmerung," in Werke in drei Bänden, vol. II (München: Hanser Verlag, 1966), Was den Deutschen abgeht, 7.

15. Eric Sheppard, "Knowledge Production Through Critical GIS: Genealogy and Prospects," Cartographica 40, no. 4 (2005): 7-8. See also David J. Bodenhamer, John Corrigan, and Trevor M. Harris, eds., The Spatial Humanities: GIS and the Future of Humanities Scholarship, Spatial Humanities (Bloomington: Indiana University Press, 2010). This volumes shares a spirit with Sheppard. Interestingly, for all the talk about local space, the imagery and maps in the volume are scientific, and a nineteenth-century positivist would have no problem understanding them.

16. Sheppard, "Knowledge Production Through Critical GIS," 8.

17. John Lewis Gaddis, The Landscape of History: How Historians Map the Past (New York: Oxford University Press, 2002).

18. See Johanna Drucker's comments in the introduction.

19. Mark S. Monmonier, How to Lie With Maps (Chicago: University of Chicago Press, 1991).

20. See, for example, Nicolas G. Rosenthal, Reimagining Indian Country: Native American Migration of Identity in Twentieth-Century Los Angeles (Chapel Hill: University of North Carolina Press, 2012). 
21. Gary Lock, "Representations of Space and Place in the Humanities," in The Spatial Humanities: GIS and the Future of Humanities Scholarship, ed. David J. Bodenhamer, John Corrigan, and Trevor M. Harris, Spatial Humanities (Bloomington: Indiana University Press, 2010), 91.

22. May Yuan, "Mapping Text," in The Spatial Humanities: GIS and the Future of Humanities Scholarship, ed. David J. Bodenhamer, John Corrigan, and Trevor M. Harris, Spatial Humanities (Bloomington: Indiana University Press, 2010), 112.

1. Elias, Time: An Essay, 44.

2. John Markoff, "Time Split to the Nanosecond Is Precisely What Wall Street Wants,” accessed July 2, 2018, www.nytimes.com/2018/06/29/technology/ computer-networks-speed-nasdaq.html.

3. Bergson, Duration and Simultaneity.

4. Bergson, Duration and Simultaneity, 50.

5. Bergson, Duration and Simultaneity, 52.

6. Alan Robert Lacey, Bergson (London and New York: Routledge, 1989), 63.

7. Bergson, Duration and Simultaneity, 49.

8. Katrina Navickas, Protest and the Politics of Space and Place 1789-1848 (Manchester: Manchester University Press, 2016).

9. Till Grallert, "Mapping Ottoman Damascus Through News Reports: A Practical Approach," in The Digital Humanities and Islamic o Middle East Studies (Berlin and Boston: De Gruyter, 2016), 175-98.

10. This problem is addressed in Ian Gregory, "Time in Historical GIS Databases," in Historical GIS: Technologies, Methodologies, and Scholarship, ed. Ian Gregory and Paul S. Ell, Cambridge Studies in Historical Geography 39 (Cambridge and New York: Cambridge University Press, 2007), 119-44.

11. Walter Benjamin, Moskauer Tagebuch, Erstausgabe (Frankfurt am Main: Suhrkamp, 1980).

12. Virgil, Aeneid 5: Text, Translation and Commentary, ed. Lee Fratantuono and R. Alden Smith, Mnemosyne. Supplements ; Monographs on Greek and Latin Language and Literature, volume 386 (Leiden and Boston: Brill, 2015), 122.

13. This translation stems from Virgil, The Aeneid, trans. C. Day Lewis (London: Hogarth Press, 1961).

14. Virgil, Aeneid 5, 442.

15. Walter Benjamin, The Writer of Modern Life: Essays on Charles Baudelaire (Cambridge, MA: Harvard University Press, 2006), 84.

16. Walter Benjamin, "Das Kunstwerk im Zeitalter seiner technischen Reproduzierbarkeit," in Illuminationen: Ausgewählte Schriften 1 (Frankfurt am Main: Suhrkamp Verlag, 1977), 140-1.

17. Corbin, Village Bells.

18. Bergson, Duration and Simultaneity, 52.

19. Clifford Geertz, "Thick Description: Toward an Interpretive Theory of Culture," in The Interpretation of Cultures: Selected Essays, 3rd ed. (New York: Basic Books, 2017).

20. Thomas Boswell, Why Time Begins on Opening Day (New York, NY: Penguin Books, 1987).

21. Friedrich Nietzsche, "Der Antichrist," in Der Fall Wagner; Götzen-Dämmerung; Der Antichrist; Ecce Homo; Dionysos-Dithyramben; Nietzsche Contra Wagner, ed. Giorgio Colli and Mazzino Montinari, Kritische Studienausgabe, KSA 6 (Berlin: De Gruyter, 1988), 254.

1. Quoted in Grete de Francesco, The Power of the Charlatan, trans. Miriam Beard (New Haven: Yale University Press, 1939), 105.

2. Burke, Eyewitnessing, 12.

3. Danto, The Transfiguration of the Commonplace. 
4. Edward R. Tufte, The Visual Display of Quantitative Information, 2nd ed. (Cheshire, CT: Graphics Press, 2001), 9.

5. Jennifer Schuessler, "Reading by the Numbers: When Big Data Meets Literature," accessed April 5, 2018, www.nytimes.com/2017/10/30/arts/francomoretti-stanford-literary-lab-big-data.html.

6. Tufte, Beautiful Evidence.

7. Tufte, The Visual Display of Quantitative Information, 53.

8. John Komlos, The Habsburg Monarchy as a Customs Union: Economic Development in Austria-Hungary in the Nineteenth Century (Princeton, NJ: Princeton University Press, 1983).

9. Paul E. Johnson, A Shopkeeper's Millennium: Society and Revivals in Rochester, New York, 1815-1837, American Century Series (New York: Hill and Wang, 1978).

10. Johnson, A Shopkeeper's Millennium, 48-50.

11. Kenneth T. Jackson, Crabgrass Frontier: The Suburbanization of the United States (New York: Oxford University Press, 1985).

12. See Peter Selb and Simon Munzert, "Examining a Most Likely Case for Strong Campaign Effects: Hitler's Speeches and the Rise of the Nazi Party, 1927-1933," American Political Science Review, 112(4), (November 2018): 1050-1066. These authors, whose background in political science explains the extensive quantitative analysis, build upon the qualitative work in Ludolf Herbst, Hitlers Charisma: Die Erfindung eines deutschen Messias (Frankfurt am Main: S. Fischer, 2010). See also Claudia Schwartz, "Der Mythos von Hitlers Charisma I NZZ,” Neue Zürcher Zeitung, August 10, 2018, www.nzz.ch/feuilleton/ der-mythos-von-hitlers-charisma-ld.1409935.

13. Matthew Bloch and Wilson Andrews, "How Every New York City Neighborhood Voted in the Republican Primary," accessed April 4, 2018, www. nytimes.com/interactive/2016/04/19/us/elections/new-york-city-republicanprimary-results.html.

14. Motoko Rich, Amanda Cox, and Matthew Bloch, "Money, Race and Success: How Your School District Compares," accessed April 4, 2018, www. nytimes.com/interactive/2016/04/29/upshot/money-race-and-success-howyour-school-district-compares.html.

15. Max Galka, "Here's Everyone Who's Immigrated to the U.S. Since 1820," Metrocosm (blog), May 3, 2016, http://metrocosm.com/animated-immigrationmap/.

16. Deleuze, "Postscript on the Societies of Control."

17. Kuhn, "The Function of Measurement in Modern Physical Science."

18. Jacques Bertin, Sémiologie graphique: Les diagrammes, les réseaux, les cartes (Paris: Gauthier-Villars, 1967).

19. Bertin, Sémiologie graphique, 220-1.

20. Bertin, Sémiologie graphique, 352.

21. They can be seen at www.jerthorp.com/365.

22. Edward R. Tufte, Visual Explanations: Images and Quantities, Evidence and Narrative (Cheshire, CT: Graphics Press, 1997), 13.

23. Metz, Language and Cinema, 21.

24. Metz, Language and Cinema, 35.

25. Metz, Language and Cinema, 34.

26. C. L. Hardin, Color for Philosophers: Unweaving the Rainbow (Indianapolis: Hackett Pub. Co, 1988).

1. Rudolf Arnheim, "On Duplication," in The Forger's Art: Forgery and the Philosophy of Art, ed. Denis Dutton (Berkeley: University of California Press, 1983), 234.

2. Thierry Lenain, Art Forgery: The History of a Modern Obsession (London: Reaktion Books, 2011), 8. 
3. See Arthur C. Danto, After the End of Art: Contemporary Art and the Pale of History, The A.W. Mellon Lectures in the Fine Arts 1995 (Princeton, NJ: Princeton University Press, 1997), 209-10.

4. Stephen Eric Bronner, A Rumor About the Jews: Antisemitism, Conspiracy, and the Protocols of Zion (Oxford and New York: Oxford University Press, 2003).

5. Nelson Goodman differentiates between forgery in the different arts. See Nelson Goodman, "Art and Authenticity," in The Forger's Art: Forgery and the Philosophy of Art, ed. Denis Dutton (Berkeley: University of California Press, 1983).

6. Jorge Luis Borges, "Pierre Menard, Author of the Quixote," in Collected Fictions (New York, NY: Viking, 1998). This is taken up in Danto, The Transfiguration of the Commonplace, 33-36. See also Monroe C. Beardsley, "Notes on Forgery," in The Forger's Art: Forgery and the Philosophy of Art, ed. Denis Dutton (Berkeley: University of California Press, 1983).

7. Ginzburg, "Clues: Roots of an Evidential Paradigm."

8. See Mark Ruwedel, Westward: The Course of Empire (New Haven, CT: Yale University Art Gallery: Distributed by Yale University Press, 2008).

9. Arthur Conan Doyle, "Speckled Band," in Sherlock Holmes: The Major Stories With Contemporary Critical Essays, ed. John A. Hodgson (Boston: Bedford Books of St. Martin Press, 1994), 152-73.

10. Arthur Conan Doyle, The Sign of Four (New York: Quality Paperback Book Club, 1994), 10.

11. In the 1980s and 1990s, any intermediary was accused of being designed to return the appropriate measurement; a measurement device such as a microscope was not merely an objective eyeball. The magnifying glass in this version skews reality.

12. Rudolf Arnheim, "On Duplication," in The Forger's Art: Forgery and the Philosophy of Art, ed. Denis Dutton (Berkeley: University of California Press, 1983), 234.

13. https://sites.google.com/site/digihumanlab/home.

14. Ahmed Elgammal, "Which Paintings Were the Most Creative of Their Time? An Algorithm May Hold the Answers," The Conversation, July 30, 2015, https://theconversation.com/which-paintings-were-the-most-creative-oftheir-time-an-algorithm-may-hold-the-answers-43157.

15. Ahmed Elgammal, "Computer Science Can Only Help-Not Hurt-Art Historians," The Conversation, December 4, 2014, https://theconversation.com/ computer-science-can-only-help-not-hurt-art-historians-33780.

1. Drucker, "Humanistic Theory and Digital Scholarship," 88.

Anderson, Chris. "The End of Theory: The Data Deluge Makes the Scientific Method Obsolete.” WIRED. Accessed April 24, 2018. www.wired.com/2008/06/ pb-theory/.

Arnheim, Rudolf. “On Duplication.” In The Forger's Art: Forgery and the Philosophy of Art, edited by Denis Dutton. Berkeley: University of California Press, 1983.

Barthes, Roland. La chambre claire: Note sur la photographie. Paris: Cahiers du cinéma, 1980.

Beard, Charles A. "That Noble Dream.” The American Historical Review 41, no. 1 (October 1935): 74-87.

Beardsley, Monroe C. "Notes on Forgery." In The Forger's Art: Forgery and the Philosophy of Art, edited by Denis Dutton. Berkeley: University of California Press, 1983. 
Benjamin, Walter. "Das Kunstwerk im Zeitalter seiner technischen Reproduzierbarkeit.” In Illuminationen: Ausgewählte Schriften 1. Frankfurt a. M: Suhrkamp Verlag, 1977.

—. Moskauer Tagebuch. Erstausgabe. Frankfurt am Main: Suhrkamp, 1980. . The Writer of Modern Life: Essays on Charles Baudelaire. Cambridge, MA: Harvard University Press, 2006.

Berger, John. Ways of Seeing. London: British Broadcasting Corp.; New York: Penguin Books, 1972.

Bergson, Henri. Duration and Simultaneity: With Reference to Einstein's Theory. Indianapolis: Bobbs-Merrill, 1965.

Berkowitz, Peter. Nietzsche: The Ethics of an Immoralist. Cambridge, MA: Harvard University Press, 1996.

Berlin, Isaiah. Historical Inevitability. Auguste Comte Memorial Trust Lecture 1. London: Oxford University Press, 1954.

Bernstein, Leonard. Leonard Bernstein at Harvard: "The Unanswered Question," Norton Lectures 1973. Videorecording. Kultur, 1992.

Bertin, Jacques. Sémiologie graphique: Les diagrammes, les réseaux, les cartes. Paris: Gauthier-Villars, 1967.

Bloch, Matthew, and Wilson Andrews. "How Every New York City Neighborhood Voted in the Republican Primary.” Accessed April 4, 2018. www.nytimes. com/interactive/2016/04/19/us/elections/new-york-city-republican-primaryresults.html.

Bloom, Allan. The Closing of the American Mind. New York: Simon and Schuster, 1988.

Bodenhamer, David J. "The Spatial Humanities: Space, Time and Place in the New Digital Age.” In History in the Digital Age, edited by Toni Weller. London and New York: Routledge, 2013.

Bodenhamer, David J., John Corrigan, and Trevor M. Harris, eds. The Spatial Humanities: GIS and the Future of Humanities Scholarship. Spatial Humanities. Bloomington: Indiana University Press, 2010.

Borges, Jorge Luis. "Pierre Menard, Author of the Quixote." In Collected Fictions. New York, NY: Viking, 1998.

Bosker, Story by Bianca. "Why Everything Is Getting Louder." The Atlantic, November 2019. www.theatlantic.com/magazine/archive/2019/11/the-end-ofsilence/598366/.

Boswell, Thomas. Why Time Begins on Opening Day. New York, NY: Penguin Books, 1987.

Bronner, Stephen Eric. A Rumor about the Jews: Antisemitism, Conspiracy, and the Protocols of Zion. Oxford and New York: Oxford University Press, 2003.

Burke, Peter. Eyewitnessing: The Uses of Images as Historical Evidence. Picturing History Series. Ithaca, NY: Cornell University Press, 2001.

Burns, William E. The Scientific Revolution in Global Perspective. New York: Oxford University Press, 2016.

Butler, Judith. "Introduction.” In Of Grammatology, edited by Jacques Derrida, translated by Gayatri Chakravorty Spivak. Baltimore: Johns Hopkins University Press, 2016.

Carnap, Rudolf. The Logical Structure of the World. Translated by Rolf A. George. Berkeley, CA: University of California Press, 1967.

Carr, Edward Hallett. What Is History? 1961. New York: Vintage Books, 1961. 
Chakrabarty, Dipesh. Provincializing Europe: Postcolonial Thought and Historical Difference. Princeton, NJ: Princeton University Press, 2000.

Cheshire, James, and Oliver Uberti. Where the Animals Go: Tracking Wildlife with Technology Technology in 50 Maps and Graphics. New York: W. W. Norton \& Company, 2017.

Chun, Wendy Hui Kyong. Programmed Visions: Software and Memory. Cambridge, MA: MIT Press, 2011.

Clark, Maudemarie. Nietzsche on Truth and Philosophy. Modern European Philosophy. Cambridge: Cambridge University Press, 1990.

Collins, Patricia Hill. "Learning from the Outsider Within: The Sociological Significance of Black Feminist Thought.” Social Problems 33, no. 6 (1986): S1432. https://doi.org/10.2307/800672.

Comrie, Bernard. "Causative Verb Formation and Other Verb-Deriving Morphology." In Grammatical Categories and the Lexicon, edited by Timothy Shopen, III: 309-48. Language Typology and Syntactic Description. Cambridge: Cambridge University Press, 1985.

Comte, Auguste. The Positive Philosophy of Auguste Comte. Translated by Harriet Martineau. Vol. I. London: G. Bell and Sons, 1896.

- The Positive Philosophy of Auguste Comte. Translated by Harriet Martineau. Vol. II. London: G. Bell and Sons, 1896.

Conant, James Bryant. On Understanding Science: An Historical Approach. New Haven: Yale University Press; London: G. Cumberlege, Oxford University Press, 1947.

Conrad, Alfred H., and John Robert Meyer. The Economics of Slavery, and Other Studies in Econometric History. Chicago: Aldine Pub. Co, 1964.

Corbin, Alain. Village Bells: Sound and Meaning in the 19th-Century French Countryside. European Perspectives. New York: Columbia University Press, 1998.

Danto, Arthur C. After the End of Art: Contemporary Art and the Pale of History. The A.W. Mellon Lectures in the Fine Arts 1995. Princeton, NJ: Princeton University Press, 1997.

—. Analytical Philosophy of History. Cambridge: Cambridge University Press, 1965.

- Nietzsche as Philosopher. New York: Columbia University Press, 2005.

- The Transfiguration of the Commonplace: A Philosophy of Art. Cambridge, MA: Harvard University Press, 1981.

Davidson, Donald. "Indeterminism and Antirealism." In Subjective, Intersubjective, Objective, 69-84. Oxford : New York: Oxford University Press, 2001.

De Kruif, Paul. Microbe Hunters. San Diego: Harcourt, Inc, 1996.

Deleuze, Gilles. "Postscript on the Societies of Control." October 59 (1992): 3-7.

Derrida, Jacques. Limited Inc. Evanston, IL: Northwestern University Press, 1988. Margins of Philosophy. Translated by Alan Bass. Chicago: University of Chicago Press, 1982.

- Of Grammatology. Translated by Gayatri Chakravorty Spivak. Baltimore: Johns Hopkins University Press, 2016.

Dilthey, Wilhelm. Introduction to the Human Sciences. Vol. 1. Princeton, NJ: Princeton University Press, 1989.

Domingos, Pedro. The Master Algorithm: How the Quest for the Ultimate Learning Machine Will Remake Our World. New York, NY: Basic Books, 2015. 
Doyle, Arthur Conan. The Sign of Four. New York: Quality Paperback Book Club, 1994.

—_. "Speckled Band." In Sherlock Holmes: The Major Stories with Contemporary Critical Essays, edited by John A. Hodgson, 152-73. Boston: Bedford Books of St. Martin Press, 1994.

Drucker, Johanna. "Humanistic Theory and Digital Scholarship." In Debates in the Digital Humanities. Minneapolis: University of Minnesota Press, 2012.

Dutton, Denis, ed. The Forger's Art: Forgery and the Philosophy of Art. Berkeley: University of California Press, 1983.

Elgammal, Ahmed. "Computer Science Can Only Help-Not Hurt-Art Historians." The Conversation, December 4, 2014. https://theconversation.com/ computer-science-can-only-help-not-hurt-art-historians-33780.

- "Which Paintings Were the Most Creative of Their Time? An Algorithm May Hold the Answers." The Conversation, July 30, 2015. https:// theconversation.com/which-paintings-were-the-most-creative-of-their-timean-algorithm-may-hold-the-answers-43157.

Elias, Norbert. Time: An Essay. Oxford: B. Blackwell, 1992.

Ellenberg, Jordan. "Opinion: How Computers Turned Gerrymandering into a Science.” The New York Times, October 6, 2017, sec. Opinion. www.nytimes. com/2017/10/06/opinion/sunday/computers-gerrymandering-wisconsin.html.

Erwig, Martin. Once upon an Algorithm: How Stories Explain Computing. Cambridge, MA: The MIT Press, 2017.

Finn, Ed. What Algorithms Want: Imagination in the Age of Computing. Cambridge, MA: MIT Press, 2017.

Fogel, Robert William, and Geoffrey Rudolph Elton. Which Road to the Past? Two Views of History. New Haven: Yale University Press, 1983.

Foucault, Michel. The Birth of the Clinic: An Archaeology of Medical Perception. New York: Pantheon Books, 1973.

- Les mots et les choses: Une archéologie des sciences humaines. Paris: Gallimard, 1990.

—. "Nietzsche, Genealogy, History.” In The Foucault Reader, edited by Paul Rabinow. 1st ed. New York: Pantheon Books, 1984.

- The Order of Things: An Archaeology of the Human Sciences. New York: Vintage Books, 1970.

Foucault, Michel, and Colin Gordon. Power/Knowledge: Selected Interviews and Other Writings, 1972-1977. 1st American ed. New York: Pantheon Books, 1980.

Francesco, Grete de. The Power of the Charlatan. Translated by Miriam Beard. New Haven: Yale University Press, 1939.

Frege, Gottlob. The Foundations of Arithmetic: A Logico-Mathematical Enquiry into the Concept of Number. New York: Philosophical Library, 1950.

Frith, Clifford B. Charles Darwin's Life with Birds: His Complete Ornithology. New York, NY: Oxford University Press, 2016.

Fukuyama, Francis. The End of History and the Last Man. New York: Free Press, 1992.

Fung, Brian. "If You Search Google Maps for the N-Word, It Gives You the White House." Washington Post, May 19, 2015. www.washingtonpost.com/news/ the-switch/wp/2015/05/19/if-you-search-google-maps-for-the-n-word-it-givesyou-the-white-house/. 
Gaddis, John Lewis. The Landscape of History: How Historians Map the Past. New York: Oxford University Press, 2002.

Galka, Max. “Here's Everyone Who's Immigrated to the U.S. Since 1820.” Metro$\operatorname{cosm}$ (blog), May 3, 2016. http://metrocosm.com/animated-immigration-map/.

Galton, Francis. Hereditary Genius: An Inquiry into Its Laws and Consequences. London: Macmillan and Co, 1869.

Gane, Mike. Auguste Comte. Key Sociologists. London and New York: Routledge, 2006.

Gauger, Hans-Martin, and Herbert Heckmann. Wir sprechen anders: Warum Computer nicht sprechen können: Eine Publikation der Deutschen Akademie für Sprache und Dichtung. Frankfurt am Main: Fischer, 1988.

Geertz, Clifford. Available Light: Anthropological Reflections on Philosophical Topics. Princeton, NJ: Princeton University Press, 2000.

- "Thick Description: Toward an Interpretive Theory of Culture." In The Interpretation of Cultures: Selected Essays. 3rd ed. New York: Basic Books, 2017.

Gillespie, Tarleton. "The Relevance of Algorithms." In Media Technologies: Essays on Communication, Materiality, and Society, edited by Tarleton Gillespie, Pablo J. Boczkowski, and Kirsten A. Foot. Cambridge, MA: The MIT Press, 2014.

Ginzburg, Carlo. “Clues: Roots of an Evidential Paradigm.” In Clues, Myths, and the Historical Method. Baltimore: Johns Hopkins University Press, 1989.

Gold, Matthew K., ed. Debates in the Digital Humanities. Minneapolis: University of Minnesota Press, 2012.

Gold, Matthew K., and Lauren F. Klein, eds. Debates in the Digital Humanities 2016. Minneapolis and London: University of Minnesota Press, 2016.

Goodman, Nelson. "Art and Authenticity." In The Forger's Art: Forgery and the Philosophy of Art, edited by Denis Dutton. Berkeley: University of California Press, 1983.

Grallert, Till. "Mapping Ottoman Damascus through News Reports: A Practical Approach." In The Digital Humanities and Islamic \& Middle East Studies, 175-98. Berlin and Boston: De Gruyter, 2016.

Gregory, Ian. “Time in Historical GIS Databases.” In Historical GIS: Technologies, Methodologies, and Scholarship, edited by Ian Gregory and Paul S. Ell, 119-44. Cambridge Studies in Historical Geography 39. Cambridge and New York: Cambridge University Press, 2007.

Grimmelmann, James. “The Google Dilemma.” New York Law School Law Review 53 (September 2008): 939-50.

Guenther, Rebecca, and Leslie Myrick. "Archiving Web Sites for Preservation and Access: MODS, METS, and MINERVA.” In Archives and the Digital Library, edited by William E. Landis and Robin L. Chandler, 141-66. Binghamton, NY: Haworth Information Press, 2006.

Hacking, Ian. The Emergence of Probability: A Philosophical Study of Early Ideas about Probability, Induction and Statistical Inference. 2nd ed. Cambridge and New York: Cambridge University Press, 2006.

Hamer, Bent. Kitchen Stories, 2003.

Hanson, Stephen E. Time and Revolution: Marxism and the Design of Soviet Institutions. Chapel Hill, NC: University of North Carolina Press, 1997.

Hardin, C. L. Color for Philosophers: Unweaving the Rainbow. Indianapolis: Hackett Pub. Co, 1988. 
Hayles, Katherine. My Mother Was a Computer: Digital Subjects and Literary Texts. Chicago: University of Chicago Press, 2005.

Heidegger, Martin. Being and Time. Translated by John Macquarrie and Edward Robinson. London: SCM Press, 1962.

—. "Der Weg zur Sprache.” In Unterwegs zur Sprache. Frankfurt am Main: Vittorio Klostermann, 1985.

—. "Die Sprache.” In Unterwegs zur Sprache. Frankfurt am Main: Vittorio Klostermann, 1985.

—. Holzwege. Frankfurt am Main: V. Klostermann, 1950.

___ "Nietzsches Wort "Gott ist tot." In Holzwege. Frankfurt am Main: V. Klostermann, 1950.

- Off the Beaten Track. Edited by Julian Young and Kenneth Haynes. Cambridge and New York: Cambridge University Press, 2002.

- "Science and Reflection." In The Question Concerning Technology and Other Essays, translated by William Lovitt. New York: Harper Perennial, 2013.

- Was heisst Denken? Frankfurt am Main: Vittorio Klostermann, 2002.

Herbst, Ludolf. Hitlers Charisma: Die Erfindung eines deutschen Messias. Frankfurt am Main: S. Fischer, 2010.

Herder, Johann Gottfried. Abhandlung über den Ursprung der Sprache. Stuttgart: Reclam, 1969.

Hewitt, Kenneth. "Excluded Perspectives in the Social Construction of Disaster." In What Is a Disaster? Perspectives on the Question, edited by E. L. Quarantelli, 75-92. London and New York: Routledge, 1998.

Hill Collins, Patricia. Black Feminist Thought: Knowledge, Consciousness, and the Politics of Empowerment. New York: Routledge, 2000.

Hvistendahl, Mara. "In China, a Three-Digit Score Could Dictate Your Place in Society." WIRED. Accessed July 2, 2018. www.wired.com/story/age-of-socialcredit/.

Iggers, Georg G. The German Conception of History: The National Tradition of Historical Thought from Herder to the Present. Middletown, CT: Wesleyan University Press, 1983.

Jackson, Kenneth T. Crabgrass Frontier: The Suburbanization of the United States. New York: Oxford University Press, 1985.

Jay, Martin. Downcast Eyes: The Denigration of Vision in Twentieth-Century French Thought. Berkeley: University of California Press, 1993.

- "In the Realm of the Senses: An Introduction." The American Historical Review 116, no. 2 (2011): 307-15.

Jenner, Mark S. R. "Follow Your Nose? Smell, Smelling, and Their Histories.” The American Historical Review 116, no. 2 (April 2011): 335-51.

Johnson, Paul E. A Shopkeeper's Millennium: Society and Revivals in Rochester, New York, 1815-1837. American Century Series. New York: Hill and Wang, 1978.

Jones, Michael N., ed. Big Data in Cognitive Science. New York, NY: Routledge, 2017.

Kennan, George. Tent Life in Siberia. Salt Lake City: Peregrine Smith Books, 1986.

Komlos, John. The Habsburg Monarchy as a Customs Union: Economic Development in Austria-Hungary in the Nineteenth Century. Princeton, NJ: Princeton University Press, 1983. 
Kotkin, Stephen. Magnetic Mountain: Stalinism as a Civilization. Berkeley: University of California Press, 1995.

Krischke, Wolfgang. "Sprachwissenschaft: Altbewährtes frischgemacht." Frankfurter Allgemeine. May 10, 2018. www.faz.net/aktuell/feuilleton/hoch-schule/ digital-humanities-eine-bilanz-1-6-sprachwissenschaft-15579104.html.

Kuhn, Thomas S. "The Function of Measurement in Modern Physical Science." Isis 52, no. 2 (June 1961): 161-93.

- The Structure of Scientific Revolutions. Chicago: University of Chicago Press, 1962.

LaCapra, Dominick. History and Reading: Tocqueville, Foucault, French Studies. Toronto and Buffalo: University of Toronto Press, 2000.

Lacey, Alan Robert. Bergson. London and New York: Routledge, 1989.

Lemov, Rebecca M. Database of Dreams: The Lost Quest to Catalog Humanity. New Haven and London: Yale University Press, 2015.

Lenain, Thierry. Art Forgery: The History of a Modern Obsession. London: Reaktion Books, 2011.

Lindenbaum, Shirley, and Margaret M. Lock, eds. Knowledge, Power, and Practice: The Anthropology of Medicine and Everyday Life. Comparative Studies of Health Systems and Medical Care. Berkeley: University of California Press, 1993.

Lock, Gary. "Representations of Space and Place in the Humanities." In The Spatial Humanities: GIS and the Future of Humanities Scholarship, edited by David J. Bodenhamer, John Corrigan, and Trevor M. Harris, 89-108. Spatial Humanities. Bloomington: Indiana University Press, 2010.

Markoff, John. "Time Split to the Nanosecond Is Precisely What Wall Street Wants.” Accessed July 2, 2018. www.nytimes.com/2018/06/29/technology/ computer-networks-speed-nasdaq.html.

Megill, Allan. Prophets of Extremity: Nietzsche, Heidegger, Foucault, Derrida. Berkeley: University of California Press, 1985.

Metz, Christian. Language and Cinema. Vol. 26. The Hague: Mouton, 1974.

Milligan, Ian. History in the Age of Abundance? How the Web Is Transforming Historical Research. Montreal; Kingston: McGill-Queen's University Press, 2019.

Monmonier, Mark S. How to Lie with Maps. Chicago: University of Chicago Press, 1991.

Moretti, Franco. Distant Reading. London: Verso, 2013.

Muhanna, Elias. "Islamic and Middle East Studies and the Digital Turn." In The Digital Humanities and Islamic \& Middle East Studies. Berlin and Boston: De Gruyter, 2016.

Navickas, Katrina. Protest and the Politics of Space and Place 1789-1848. Manchester: Manchester University Press, 2016.

Newman, William. “A Preliminary Reassessment of Newton's Alchemy.” In Cambridge Companion to Newton. Cambridge: Cambridge University Press, 2016.

Ng, Kwong Bor, Jason Kucsma, and Metropolitan New York Library Council, eds. Digitization in the Real World: Lessons Learned from Small and MediumSized Digitization Projects. New York: Metropolitan New York Library Council, 2010.

Nietzsche, Friedrich. “Die Philosophie im tragischen Zeitalter der Griechen.” In Werke in drei Bänden. Vol. 3. München: Carl Hanser, 1966. 
. “Götzendämmerung.” In Werke in drei Bänden. Vol. II. München: Hanser Verlag, 1966.

—_. “Zur Genealogie der Moral.” In Werke in drei Bänden. Vol. II. München: Hanser Verlag, 1966.

Noble, Safiya Umoja. Algorithms of Oppression: How Search Engines Reinforce Racism. New York: New York University Press, 2018.

Novick, Peter. That Noble Dream: The "Objectivity Question" and the American Historical Profession. Cambridge: Cambridge University Press, 1988.

Oliveira, Arlindo L. The Digital Mind: How Science Is Redefining Humanity. Cambridge, MA: The MIT Press, 2017.

Pasquale, Frank. The Black Box Society: The Secret Algorithms that Control Money and Information. Cambridge, MA and London: Harvard University Press, 2015.

Paul, Gerhard, and Ralph Schock, eds. Sound der Zeit: Geräusche, Töne, Stimmen: 1889 bis heute. Göttingen: Wallstein, 2014.

Pinker, Steven. The Stuff of Thought: Language as a Window into Human Nature. New York: Viking, 2007.

Prost, Antoine. Republican Identities in War and Peace: Representations of France in the Nineteenth and Twentieth Centuries. The Legacy of the Great War. Oxford and New York: Berg, 2002.

Proust, Marcel. Du côté de chez Swann. Paris: Gallimard, 1987.

—. Le Temps retrouvé. Paris: Gallimard, 1992.

Putnam, Lara. "The Transnational and the Text-Searchable: Digitized Sources and the Shadows They Cast." American Historical Review 121 (April 2016): 377-402.

Quine, Willard Van Orman. Word and Object. Cambridge: Technology Press of the Massachusetts Institute of Technology, 1960.

Ranke, Leopold von. "On the Character of Historical Science (A Manuscript of the 1830's)." In The Theory and Practice of History, edited by Georg G. Iggers, 8-16. London and New York: Routledge, 2011.

-. "On Progress in History (From the First Lecture to King Maximilian II of Bavaria 'On the Epochs of Modern History,' 1854)." In The Theory and Practice of History, edited by Georg G. Iggers, 20-23. London and New York: Routledge, 2011.

. "Pitfalls of a Philosophy of History (Introduction to a Lecture on Universal History; a Manuscript of the 1840's)." In The Theory and Practice of History, edited by Georg G. Iggers, 17-19. London and New York: Routledge, 2011.

Rich, Motoko, Amanda Cox, and Matthew Bloch. "Money, Race and Success: How Your School District Compares.” Accessed April 4, 2018. www.nytimes. com/interactive/2016/04/29/upshot/money-race-and-success-how-yourschool-district-compares.html.

Riskin, Jessica. Science in the Age of Sensibility: The Sentimental Empiricists of the French Enlightenment. Chicago: University of Chicago Press, 2002.

Rorty, Richard. Eine Kultur ohne Zentrum : Vier philosophische Essays und ein Vorwort. Stuttgart: Reclam, 1993.

- The Linguistic Turn: Recent Essays in Philosophical Method. Chicago: University of Chicago Press, 1967.

- Philosophy and the Mirror of Nature. Princeton, NJ: Princeton University Press, 1980. 
Rorty, Richard, Jerome B. Schneewind, and Quentin Skinner, eds. Philosophy in History: Essays on the Historiography of Philosophy. Cambridge [Cambridgeshire] and New York: Cambridge University Press, 1984.

Rosenthal, Nicolas G. Reimagining Indian Country: Native American Migration \& Identity in Twentieth-Century Los Angeles. First Peoples: New Directions in Indigenous Studies. Chapel Hill: University of North Carolina Press, 2012.

Rosenzweig, Roy. Clio Wired: The Future of the Past in the Digital Age. New York: Columbia University Press, 2011.

Ruwedel, Mark. Westward: The Course of Empire. New Haven, CT: Yale University Art Gallery: Distributed by Yale University Press, 2008.

Sahlins, Marshall. Islands of History. Chicago: University of Chicago Press, 1985.

Schafer, R. Murray. Voices of Tyranny, Temples of Silence. Arcana Editions, 1993.

Schivelbusch, Wolfgang. Disenchanted Night: The Industrialization of Light in the Nineteenth Century. Berkeley: University of California Press, 1995.

Schuessler, Jennifer. "Reading by the Numbers: When Big Data Meets Literature." Accessed April 5, 2018. www.nytimes.com/2017/10/30/arts/franco-morettistanford-literary-lab-big-data.html.

Schwartz, Claudia. "Der Mythos von Hitlers Charisma I NZZ.” Neue Zürcher Zeitung, August 10, 2018. www.nzz.ch/feuilleton/der-mythos-von-hitlerscharisma-ld.1409935.

Searle, John R. "Minds, Brains, and Programs." Behavioral and Brain Sciences 3, no. 3 (1980): 417-57.

Selb, Peter, and Simon Munzert. "Examining a Most Likely Case for Strong Campaign Effects: Hitler's Speeches and the Rise of the Nazi Party, 1927-1933.” American Political Science Review 112, no. 4 (2018): 1050-1066.

Shapin, Steven, and Simon Schaffer. Leviathan and the Air-Pump: Hobbes, Boyle, and the Experimental Life. Princeton, NJ: Princeton University Press, 1989.

Sheppard, Eric. "Knowledge Production through Critical GIS: Genealogy and Prospects." Cartographica 40, no. 4 (2005): 5-21.

Skinner, Quentin, ed. The Return of Grand Theory in the Human Sciences. Cambridge and New York: Cambridge University Press, 1990.

Skloot, Rebecca. The Immortal Life of Henrietta Lacks. New York: Crown Publishers, 2010.

Sobieszek, Robert A. Ghost in the Shell: Photography and the Human Soul, 1850-2000: Essays on Camera Portraiture. Los Angeles: Los Angeles County Museum of Art; Cambridge, MA: MIT Press, 1999.

Sokal, Alan D., ed. The Sokal Hoax: The Sham that Shook the Academy. Lincoln: University of Nebraska Press, 2000.

Spiegel, Gabrielle M. "History, Historicism, and the Social Logic of the Text." In The Past as Text: The Theory and Practice of Medieval Historiography. Parallax. Baltimore: Johns Hopkins University Press, 1997.

. The Past as Text: The Theory and Practice of Medieval Historiography. Parallax. Baltimore: Johns Hopkins University Press, 1997.

Spivak, Gayatri Chakravorty. "Afterword." In Of Grammatology, edited by Jacques Derrida. Baltimore: Johns Hopkins University Press, 2016.

- .Can the Subaltern Speak?" In Can the Subaltern Speak? Reflections on the History of an Idea, edited by Rosalind C. Morris. New York: Columbia University Press, 2010. 
. "Can the Subaltern Speak?" In Marxism and the Interpretation of Culture, edited by Cary Nelson and Lawrence Grossberg, 279-313. Urbana: University of Illinois Press, 1988.

Staten, Henry. Wittgenstein and Derrida. Lincoln and London: University of Nebraska Press, 1984.

Svensson, Patrik, and David Theo Goldberg, eds. Between Humanities and the Digital. Cambridge, MA: The MIT Press, 2015.

TechCrunch. "Eric Schmidt: Every 2 Days We Create as Much Information as We Did Up to 2003.” Accessed September 25, 2019. http://social.techcrunch. com/2010/08/04/schmidt-data/.

Tufte, Edward R. Beautiful Evidence. Cheshire, CT: Graphics Press, 2006.

- The Visual Display of Quantitative Information. 2nd ed. Cheshire, CT: Graphics Press, 2001.

- Visual Explanations: Images and Quantities, Evidence and Narrative. Cheshire, CT: Graphics Press, 1997.

Virgil. The Aeneid. Translated by C. Day Lewis. London: Hogarth Press, 1961. . Aeneid 5: Text, Translation and Commentary. Edited by Lee Fratantuono and R. Alden Smith. Mnemosyne. Supplements; Monographs on Greek and Latin Language and Literature, volume 386. Leiden and Boston: Brill, 2015.

Whaley, John H., Jr. "Digitizing History.” The American Archivist 57, no. 4 (Fall 1994): 660-72.

White, Hayden V. Metahistory: The Historical Imagination in NineteenthCentury Europe. Baltimore: Johns Hopkins University Press, 1973.

Wiesenfeldt, Christiane. “Zu viele Noten?” Frankfurter Allgemeine, May 17, 2018. www.faz.net/aktuell/feuilleton/hoch-schule/digital-humanities-eine-bilanz2-6-musikwissenschaft-15579191.html.

Wilkerson, Isabel. The Warmth of Other Suns: The Epic Story of America's Great Migration. New York: Random House, 2010.

Williams, Lucy, and Barry Godfrey. "Bringing the Prisoner into View: English and Welsh Census Data and the Victorian Prison Population.” Australian Historical Studies 47, no. 3 (September 2016): 398-413.

Wittgenstein, Ludwig. Philosophical Investigations. Edited by G. E. M. Anscombe. 3rd ed. Oxford and Malden, MA: Blackwell, 2001.

- Tractatus Logico-philosophicus. London and New York: Routledge \& Paul, 1961.

Yuan, May. "Mapping Text.” In The Spatial Humanities: GIS and the Future of Humanities Scholarship, edited by David J. Bodenhamer, John Corrigan, and Trevor M. Harris, 89-108. Spatial Humanities. Bloomington: Indiana University Press, 2010. 